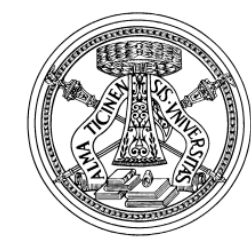

Quaderni di Dipartimento

\title{
Returns in commodities futures markets and financial speculation: a multivariate GARCH approach
}

Matteo Manera

(Università di Milano-Bicocca e Fondazione Eni Enrico Mattei)

Marcella Nicolini

(Università di Pavia)

Ilaria Vignati

(Fondazione Eni Enrico Mattei)

\# 170 (04-12)

Dipartimento di economia politica e metodi quantitativi

Università degli studi di Pavia

Via San Felice, 5

I-27100 Pavia

Aprile 2012 


\title{
Matteo Manera, ${ }^{\mathrm{a}^{*}}$ Marcella Nicolini, ${ }^{\mathrm{b}}$ and Ilaria Vignati ${ }^{\mathrm{c}}$
}

\section{Returns in commodities futures markets and financial speculation: a multivariate GARCH approach}

\begin{abstract}
This paper analyses futures prices for four energy commodities (light sweet crude oil, heating oil, gasoline and natural gas) and five agricultural commodities (corn, oats, soybean oil, soybeans and wheat), over the period 1986-2010. Using CCC and DCC multivariate GARCH models, we find that financial speculation is poorly significant in modelling returns in commodities futures while macroeconomic factors help explaining returns in commodities futures. Moreover, spillovers between commodities are present and the conditional correlations among commodities are high and time-varying.
\end{abstract}

JEL Codes: C32; G13; Q11; Q43.

Keywords: Energy; Commodities; Futures markets; Financial speculation; Multivariate GARCH.

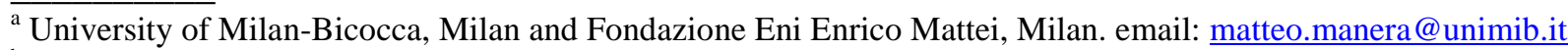

${ }^{\mathrm{b}}$ University of Pavia, Pavia and Fondazione Eni Enrico Mattei, Milan. email: marcella.nicolini@unipv.it

${ }^{\mathrm{c}}$ Fondazione Eni Enrico Mattei, Milan. email: ilaria.vignati@feem.it

* Corresponding author.
}

A previous version of this paper has been presented at the FEEM International Conference on "Financial Speculation in the Oil Market and the Determinants of the Oil Price", held in Milan, 12-13 january 2012. We would like to thank Bahattin Büyükşahin, Leo Drollas, Marzio Galeotti, Alessandro Lanza and seminar participants at FEEM, Department of Statistics, University of Milan-Bicocca, and University of Pavia for providing helpful comments. All remaining errors are our own responsibility. 


\section{Introduction}

The last decades have witnessed a number of changes in commodities futures markets. The oil market has continuously grown, becoming the world's biggest commodity market and turning from a primarily physical product activity into a sophisticated financial market (Chang et al. 2011). Secondly, the increasing presence of hedgers, as well as speculators, has led to allegations that speculation drives crude oil prices, and speculators, index funds and hedge funds have been responsible for the increase in energy and food prices from 2004 onwards (Masters 2008). The literature however has provided, so far, little empirical evidence in support of this claim.

Speculators have historically been present in non-energy commodities futures markets as well: it is therefore reasonable, while testing the role of speculators and any possible impact on commodities' returns, to extend the analysis to both energy and non-energy commodities.

Moreover, the common behaviour displayed by energy and non-energy commodities prices in recent times, characterized by a steep rise around year 2008 which has been followed by a sharp decrease during the "great recession", has posed the question of the linkage between these markets, and the spillovers that may be present.

The aim of this paper is to shed some light on these compelling questions. More precisely, we focus on four research questions. First, are macroeconomic factors relevant in explaining returns of energy and non-energy commodities? Second, is financial speculation significantly related to returns in futures markets? Third, are there significant relationships among returns, either in their mean or variance, across different markets? Finally, is speculation in one market affecting returns in other markets? Or, in other words, are there spillovers across markets in speculation?

Our empirical exercise considers weekly data over the time period 1986:3 to 2010:52. We collect data on returns of four energy commodities (gasoline, heating oil, natural gas and crude oil) and four non-energy commodities (corn, oats, soybeans and wheat). Additionally, we include in our analysis a biofuel, soybean oil, to investigate if the relationship among the latter and energy commodities is stronger than what can be found in the case of food commodities. We consider a generalized autoregressive conditional heteroskedasticity (GARCH) model to estimate commodities' returns: we first discuss an univariate analysis, where returns are explained by macroeconomic variables an a measure of speculation. Then, we present multivariate GARCH models to investigate the presence of spillovers across commodities.

Our results suggest that macroeconomic variables are relevant to explain commodities' returns, more precisely the Standard \& Poor's (S\&P) 500 index has a positive and significant coefficient, while the multilateral exchange rate has a negative effect, as expected. As concerns the second 
research question, we observe that speculation, measured by the Working's T index, does not seem to significantly affect returns. Finally, we observe that the dynamic conditional correlations among commodities are higher in recent years. As speculation is generally poorly significant, we do not detect a relevant impact on own market and other markets' returns. However, we find an interesting result concerning the speculation index in crude oil market: it assumes a positive and significant coefficient on soybean oil returns after 2004, indicating a linkage between energy markets and a biofuel one in recent times.

The remainder of this paper is structured as follows. Section 2 discusses the debate on the impact of speculation in futures markets and the presence of spillovers across commodities. Section 3 presents the data and some descriptive statistics. Section 4 describes the econometric model while Section 5 presents the results. Finally, Section 6 concludes.

\section{Literature review}

The asset pricing literature provides empirical evidence of the ability of few macroeconomic variables to forecast returns on commodities futures. The first is the return on the 90-day Treasury bill, which represents the short-term discount rate free of a risk premium. The T-bill tends to be lower during economic recessions and higher during periods of growth. Thus, it is expected to be negatively correlated with real economic output growth. A negative relationship between real commodity prices and real interest rates has been confirmed empirically (Frankel 2008a). The second variable is the equity dividend yield: futures commodity prices are expected to reflect the systemic risk embedded within the evolution of stock market conditions (Chevallier 2009). A third variable is the "junk bond premium", which is the premium on long-term corporate bonds rated BAA by Moody's over the AAA rated ones. This difference represents the monetary compensation for risk. Recent works on petroleum futures returns and carbon futures returns (Sadorsky 2002, Chevallier 2009) find however that these macroeconomic risk variables are poorly significant. Finally, exchange rates are thought to be closely related to commodities futures prices, although the direction of the causality among these variables is still debated. Indeed, Chen et al. (2010) show that exchange rates have robust forecasting power over global commodity prices and that commodity prices Granger-cause exchange rates in-sample.

Some commentators (Frankel 2008b, Mitchell 2008, Verleger 2009) suggest that the causes of price increases have to be identified in economic fundamentals as low interest rates in the USA, which forced to look for other investment opportunities. Another factor is the rapid economic growth worldwide, especially in China and India, which has been accompanied by growing demand for 
food commodities. Instability among oil producers, especially in the Middle East, and therefore uncertainty in the supply of oil has to be accounted for as well. Finally, misguided ethanol subsidies have increased biofuel production and might have affected prices. Baffes and Haniotis (2010) add to the latter argument claiming that the future path of commodities prices is uncertain due to the strict relationship between energy and non-energy prices. In particular, this relationship has increased considerably in the recent boom, indicating that events and policy changes happening in one market affect other markets. Gilbert (2010) collects data on three food price indexes over the period 1971-2008 and shows that demand-side variables (i.e. GDP growth) and monetary expansion, measured by world real money supply, are the main cause of price increase by means a Granger-causality test. Moreover, he finds that, in the last years, oil prices have had more influence on food ones thus supporting the idea of an increasing link among markets. He claims however that this is the result of common causation rather than of a direct causal link.

More recently, several researchers and analysts suggested that the increasing presence of speculators in commodity future markets could explain the spike in prices in the 2007-2008 period (see, among many, Eckaus 2008, Masters 2008, Soros 2008). Indeed, Medlock III and Jaffe (2009) show that non-commercial agents in 2009 represented about $50 \%$ of total open interest in the oil market, compared to about $20 \%$ prior to 2002 . Moreover, the open interest held by speculators moved from a lagging indicator of price to a leading indicator around January 2006, suggesting a possible cause in oil prices increase. Khan (2009) argues that speculation played a role comparing movements in the price of crude oil and the price of gold, which used to move together until 2000, while they display a gap from 2002 onwards. Robles et al. (2009) find some evidence that speculative activity, measured in turn as scalping, which is the ratio of volume to open interest, or the share of non commercial positions over total positions or the index traders' net position, Granger-causes current commodity prices of wheat, maize, soybeans and rice. Du et al. (2011) show that scalping and speculation affect positively crude oil price volatility. Moreover, after 2006, they find that the oil price shock has triggered price changes in corn and wheat markets, potentially because of an increase in ethanol production.

Other authors instead do not find a statistically significant relationship between commodity prices and index funds, which are held responsible for speculation. Index Investment Data (IID) have been made available by CFTC from December 2007. Using these data Irwin and Sanders (2012) find little evidence that IID positions influence returns or volatility in 19 commodity futures markets. Authors interested in analysing the previous period proxied index funds activity using data on swap dealers. Empirical tests provide no evidence that position changes by any trader group Granger- 
cause price changes in both energy and non-energy commodities futures markets (Brunetti and Büyükşahin 2009, Stoll and Whaley 2010, Büyükşahin and Harris 2011).

Sanders et al. (2010) study agricultural futures markets over the period 1995-2008 and show that the Working (1960)'s T index, traditionally adopted to measure excess speculation (see Section 3 for a formal definition), has remained stable or below historical levels in recent years. However, they suggest that this result might be due to the nature of the index itself: the recent rise in long speculative positions has been paralleled by an increase in short hedging, thus implying an overall decrease in the Working's $\mathrm{T}$ index.

Other authors suggest that the crude oil price spike and collapse in 2007-08, while being mainly driven by increasing world demand, can not be explained by macroeconomic factors only and suggest that speculation played a role (Kaufmann and Ulman 2009, Kaufmann 2011). We follow this approach, and in the subsequent econometric analysis we investigate the role of macroeconomic variables and speculation on futures' returns.

Another issue we tackle with the present econometric exercise is the relationship among commodities prices and price changes. The literature has largely debated on this.

Granger (1986) affirms that two series of prices can not be cointegrated as, if they were, one could be used to forecast the other, and this would go against the hypothesis of efficient markets. However, Malliaris and Urrutia (1996) test for cointegration between futures prices of six agricultural commodities (corn, wheat, oats, soybeans, soybean meal and soybean oil) over data for the period from January 1981 to October 1991 at daily frequency, finding a strong and statistically significant long-term relationships among all the six commodities, thus rejecting the hypothesis that prices of these agricultural products move independently. The authors suggest that it could be explained by substitutability and complementarity between agricultural commodities, common geographical and climatic factors, global demand shocks and the "excess co-movement hypothesis", first proposed by Pindyck and Rotemberg (1990) (see more infra). Also Chaudhuri (2001) finds cointegration between real oil prices and other real commodity prices in the period 1973-1996.

Pindyck and Rotemberg (1990) analyze monthly returns of 7 commodities (wheat, cotton, copper, gold, crude oil, lumber and cocoa) from 1960 to 1985. The commodities are chosen to be not substitutes nor complements, neither co-produced and neither inputs for others' production: they are thus expected to be uncorrelated. However, the authors find that the residuals of a regression of these commodities' prices on macroeconomic variables are highly correlated, meaning that prices move together even after accounting for a set of macroeconomic variables. This "excess comovement" is possibly explained by the so called "herd" behaviour of financial traders: "...traders 
are alternatively bullish or bearish on all commodities for no plausible economic reason" (Pindyck and Rotemberg 1990, 1173).

Subsequently, several papers have challenged the excess co-movement hypothesis. Palaskas and Varangis (1991) show the existence of co-movements but not excess co-movements between nine commodity prices. LeyBourne et al. (1994) find that only 4 out of 15 commodity prices pairs exhibit excess co-movement and that only 2 of 10 commodity prices exhibit co-movement, confirming a weak evidence of this phenomenon. Deb et al. (1996) find weak evidence of excess co-movement, Cashin et al. (1999), using a measure of concordance, ${ }^{1}$ find no evidence of comovement in the prices of unrelated commodities, but find strong evidence of co-movements in groups of related ones. Ai et al. (2006) show that, after considering commodity-specific demand and supply factors, there does not seem to be any "excess" co-movement. Finally, Vansteenkiste (2009) estimates a dynamic factor model using Kalman Filtering techniques on 32 non-fuel commodity prices from 1957 to 2008, separating between common and idiosyncratic (i.e. specific for a group of commodities) shocks in affecting prices. The main finding is that a common factor does exist and it is linked to macroeconomic fundamentals, rather then speculation in futures markets. However, from 2000 onwards, idiosyncratic effects became more relevant.

More recently the literature has concentrated on possible linkages between energy and non-energy commodities. Indeed, crude oil is an important input in agricultural production, either in the form of diesel, fertilizers or pesticides. Baffes (2007) measures the effect of crude oil prices on the prices of 35 internationally traded primary commodities for the 1960-2005 period, finding that the passthrough of crude oil price changes to the overall non-energy commodity index is 0.16 , suggesting that a $10 \%$ increase in the price of crude oil brings a $1.6 \%$ increase in the non-energy commodity prices. Baffes (2009) expands his analysis considering an index which includes also natural gas and coal and extending the sample up to 2008. This analysis finds that a $10 \%$ increase in energy prices brings a $2.8 \%$ increase in non-energy prices, suggesting that the 2008 financial crisis has strengthened the relationship between energy and non-energy prices.

The research has focussed recently also on a specific class of commodities, biofules, and on the possible linkages between biofuels and other food commodities. The corn designed to ethanol production in the U.S. was $10 \%$ of total crop in 2002/03 and ran up to $24 \%$ in $2007 / 08$ (Trostle 2008). Actually, Natanelov et al. (2011) show a lack of cointegration between corn and crude oil price between mid 2004 and July 2006, which is due to policy interventions on biofules. However, after surpassing a certain threshold in crude oil price the two series are cointegrated. Ciaian and Kanks (2011) show that the interdependencies among crude oil and agricultural commodities

\footnotetext{
${ }^{1}$ Concordance measures the extent to which the cycles of two series are synchronized. It is a useful concept of comovement because it represents a way to summarize information on the economic phases of commodity prices.
} 
(included corn and soybean) are increasing over time: significant cointegrating relationships are detected only after 1994. FAO (2009) as well suggests that the main drivers of the agricultural prices boom are demand factors (mainly biofuel demand) and high oil prices, which have a direct impact on the costs of agricultural production.

\section{Data description}

We collect data on futures prices for four energy commodities (light sweet crude oil, heating oil, gasoline and natural gas) and five agricultural commodities (corn, oats, soybean oil, soybeans and wheat). All the energy commodities are traded on the New York Mercantile Exchange (NYMEX), while the agricultural ones are traded on Chicago Board of Trade (corn, oats, soybean oil and soybeans) and Kansas City Board of Trade (wheat). Daily data are retrieved from Datastream and then turned into weekly averages of futures prices ${ }^{2}$ for each commodity. Indeed, data necessary to build the speculation index are provided by the Commitments of Traders (COT) reports of U.S. Commodity Futures Trading Commission (CFTC) on a weekly basis, thus we have to adopt this data frequency. CFTC collects every week the open interest for specific categories of traders: commercial (hedgers) ${ }^{3}$ and non-commercial (speculators and arbitrageurs), ${ }^{4}$ distinguishing between short and long positions. The period considered spans from 1986:3 to 2010:52. ${ }^{5}$ Table 1 provides some reference on the series employed in the analysis.

The data collected allow to calculate the Working's T (1960) index, which is a measure of speculative activity that proxies the excess of speculation relative to hedging activity. This index is calculated as the ratio of non-commercial positions to total commercial positions:

$$
\left\{\begin{array}{lll}
1+\frac{S S}{H S+H L} & \text { if } & H S \geq H L \\
1+\frac{S L}{H S+H L} & \text { if } & H S<H L
\end{array}\right.
$$

\footnotetext{
${ }^{2}$ We use the continuous futures price series, calculated by Thomson Financial. They start at the nearest contract month which forms the first values for the continuous series and switch over on $1^{\text {st }}$ day of new trading month.

${ }^{3}$ Commercial agents are also active in the spot market. In this category CFTC includes producers, merchants, processors and users, i.e. who use futures markets to manage or hedge risks associated with the physical activity of commodities, and swap dealers, i.e. all the agents who use these markets to manage or hedge the risk associated with swap transactions.

${ }^{4}$ Non-commercial agents are in futures markets to make profits from selling and buying futures contracts. In this category CFTC includes money managers, i.e. a category which includes a registered commodity trading advisor (CTA), a registered commodity pool operator (CPO) or an unregistered fund identified by CFTC, and other reportables, i.e. any trader that is not identified in the previous categories.

${ }^{5}$ From January 1986 to September 1992 CFTC reports data with bi-monthly frequency. Missing data are replaced by the average between the previous and the following observation.
} 
where $S S$ is speculation short (open interest held by speculators who sell futures contracts), $S L$ is speculation long (open interest held by speculators who have long positions), $H S$ is hedging short and $H L$ is hedging long.

It should be noted that the calculation of the Working's $\mathrm{T}$ index crucially depends on the classification of the market operators between hedgers and speculators. CFTC also provides data for "Non Reportable" operators, ${ }^{6}$ which are not classified into any of the two categories. However, open interest held by these subjects should be included in the computation of the index. Several rules to treat them are at hand. One could consider them as being all hedgers or, more likely, all speculators. Indeed, hedgers are generally known by CFTC and are less likely to be unknown. We follow an intermediate approach, assuming that $70 \%$ of them are speculators and $30 \%$ are hedgers. ${ }^{7}$ However, we calculate the speculation index also in the two "extreme" hypotheses and perform the econometric exercise with these variables. ${ }^{8}$

To control for macroeconomic factors we collect daily (5 days) data, which we turn into weekly averages, on Moody's AAA and BAA corporate bond yield, 3-month Treasury bill, S\&P 500 index and a weighted exchange rate index of the U.S. dollar against a subset of broad index currencies outside U.S. for the period 01/02/1986 - 12/31/2010 from the Federal Reserve Economic Data (FRED) provided by the Federal Reserve of St. Louis. ${ }^{9}$

Descriptive statistics of the variables are reported in Table 2. The table is divided in four panels, one for each set of variables. Futures prices and macroeconomic variables contain a unit root, as the Augmented Dickey-Fuller (ADF) test statistics does not reject the null hypothesis for almost all series in the dataset. Therefore, for each commodity we consider the return $r_{i t}$, which is defined as $\log \left(P_{i t} / P_{i t-1}\right)$, where $P_{i t}$ and $P_{i t-1}$ are the prices of commodity $i$ at weeks $t$ and $t-1$, respectively. This transformation allows to obtain stationarity, as shown in the second panel of Table 2.

\footnotetext{
${ }^{6}$ CFTC defines this category as follows: "The long and short open interest shown as "Non Reportable Positions" is derived by subtracting total long and short "Reportable Positions" from the total open interest. Accordingly, for "Non Reportable Positions," the number of traders involved and the commercial/non-commercial classification of each trader are unknown." (see http://www.cftc.gov/MarketReports/CommitmentsofTraders/ExplanatoryNotes/index.htm)

7 So, in (1), SS comprises "Money Manager" short, "Other Reportables" short and 70\% of "Non Reportable" short; SL comprises "Money Manager" long, "Other Reportables" long and 70\% of "Non Reportables" long; HS comprises "Producer/Merchant/Processor/User" short, "Swap Dealer" short, "Swap Dealer Spread" (in the "Spread" category are included traders that go both long and short on futures markets) and 30\% of "Non Reportable" short; HL comprises "Producer/Merchant/Processor/User" long, "Swap Dealer" long, "Swap Dealer Spread" and 30\% of "Non Reportable" long.

${ }^{8}$ Results are similar using alternative definitions of the Working's $\mathrm{T}$ index. They can be found in the technical appendix available from the authors upon request.

${ }^{9}$ The trade weighted exchange index is defined as a weighted average of the foreign exchange value of the U.S. dollar against a subset of the broad index currencies that circulate widely outside the country of issue. Major currency index includes the Euro Area, Canada, Japan, United Kingdom, Switzerland, Australia, and Sweden. According to this definition, a decrease of the index corresponds to a depreciation of the U.S. dollar.
} 
Figure 1 reports the behaviour of futures prices over the time period considered. The plots confirm that futures prices are not stationary. Moreover, we observe that both energy and agriculture commodities display a spike in prices in $2008 .^{10}$

As said before, Working's T index measures the excess of speculation relative to hedging activity: if it is equal, for example, to 1.2 , it indicates $20 \%$ of speculation in excess of what is necessary to meet hedging needs. By construction, the minimum value is 1 , when there is not any excess speculation in the market. The third panel of Table 2 shows that Working's $\mathrm{T}$ index ranges from mean values of $10.5 \%$ (in gasoline) to $26.8 \%$ (in soybeans) and, in the entire sample, it reaches maximum values of around more than $50 \%$ (in natural gas and oats). The index is stationary in levels and therefore it is not transformed.

However, the long time span considered in our sample may, on average, conceal the role of speculation in recent times. We then report summary statistics for two different periods: 1986-2003 and 2004-2010 to inspect if any change of this index occurred across different commodities over time. We choose 2004 as in this year the oil demand exceptionally reaches a record level of almost 3 millions barrels a day ${ }^{11}$ and the S\&P GSCI (Goldman Sachs Commodity Index) sharply accelerates. Results are reported in Table 3. First, we observe that in the 1986-2003 period energy commodities display lower mean values than non-energy ones. Second, mean values are generally lower in the 2004-2010, with the notable exception of natural gas, crude oil and wheat: as these commodities show higher values in the second period, this suggests that speculation has increased in recent times.

The contemporaneous rise in agricultural and energy prices, reported in Figure 1, poses the question of the linkages between these markets and the spillovers that may take place: preliminary evidence is provided by the correlation matrix between the variables employed in the estimation, presented in Table 4. The highest correlations are those between returns of energy commodities (generally higher that 0.7 ), while soybean oil, notwithstanding its widespread use as fuel, is poorly correlated with them. Correlations between returns and Working's T indexes are in almost all cases not significant, suggesting that the relationship linking these variables is weak and anticipating the result found in the econometric analysis that speculation is not relevant in explaining futures returns. Correlations between speculation indexes are generally not large and mixed in sign but always significant.

\footnotetext{
${ }^{10}$ For gasoline, heating oil, crude oil, soybean oil, corn, oats and soybeans the spike corresponds to the $27^{\text {th }}$ week (July) of 2008; for wheat it is the $11^{\text {th }}$ week (March) of 2008; for natural gas we find two peaks: in the $50^{\text {th }}$ week (December) of 2005 and in the $27^{\text {th }}$ week (July) of 2008 .

${ }^{11}$ See U.S. Energy Information Administration (2008).
} 


\section{The econometric specification}

We aim at modelling the returns of commodities' futures prices. As a preliminary step, we test for stationarity of all the series, and take the difference in logs if necessary (see Table 2). Then, we estimate the following equation:

$r_{i t}=\alpha_{0}+\alpha_{1}$ int_rate $_{t}+\alpha_{2}$ junk_bond_yield ${ }_{t}+\alpha_{3} S \& P_{t}+\alpha_{4}$ exc_rate ${ }_{t}+\alpha_{5} W T_{i t}+\varepsilon_{i t}$

where the dependent variable is the return in commodity market $i$ at time $t$. The macroeconomic

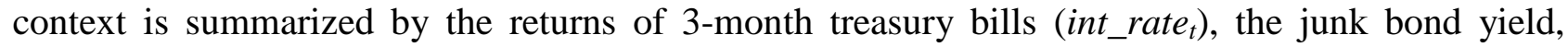
which is defined as the difference between BAA and AAA corporate bond yield, the returns of the S\&P 500 index $\left(S \& P_{t}\right)$ and the exchange rate between U.S. dollar and other currencies, and the speculation present in markets, represented by the Working's $\mathrm{T}\left(W T_{i t}\right)$ for the market $i$ at time $t$. We consider nine markets and the time period spans from 1986:3 to 2010:52. ${ }^{12}$

We first estimate the model with ordinary least squares (OLS) and test for autoregressive conditional heteroskedasticity $(\mathrm{ARCH})$ effects in the residuals. If such effects are present, we revert to a generalized conditional heteroskedasticity $(\mathrm{GARCH})$ model. If the GARCH term is statistically significant, we opt for a $\operatorname{GARCH}(1,1)$ model, controlling that the second moment and log moment conditions are respected. We also test for autocorrelation in the residuals and include an auto regressive term if necessary.

As will be discussed in the next section, the GARCH $(1,1)$ model with an $\operatorname{AR}(1)$ term is the preferred specification to model the returns. Therefore, we end up estimating a model where the conditional mean equation is:

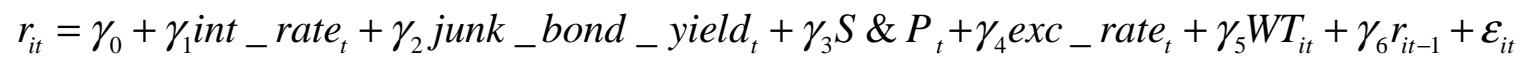

and the conditional variance is defined as:

$\sigma_{i t}^{2}=s_{i}+\sum_{j=1}^{p_{i}} \alpha_{j} \varepsilon_{i t-j}^{2}+\sum_{j=1}^{q_{i}} \beta_{j} \sigma_{i t-j}^{2}$

\footnotetext{
${ }^{12}$ For natural gas data are available from 1990:14.
} 
where the variance $\sigma_{i t}^{2}$ of the regression model's disturbances is a linear function of lagged values of the squared regression disturbances and of its past value: $p$ defines the order of the ARCH term, and $q$ of the GARCH term. In the econometric exercise, we estimate a model where $p=q=1$.

The univariate analysis is however limited in its scope: the common trend in futures prices, shown in Figure 1, suggests that a multivariate approach should be implemented to investigate the presence of spillovers, both in the mean and in the variance equation. Indeed, a multivariate-GARCH model captures the effects on current volatility of own innovation and lagged volatility shock originated in a given market, as well as cross innovation and volatility spillovers from other futures markets. This allows to better understand volatility, as well as volatility persistence, in interconnected markets. A general multivariate GARCH model is defined as:

$$
\begin{aligned}
& r_{t}=C x_{t}+\varepsilon_{t} \\
& \varepsilon_{t}=H_{t}^{1 / 2} v_{t}
\end{aligned}
$$

where $r_{t}$ is an $m \times 1$ vector of dependent variables, $\mathrm{C}$ is an $m \times k$ matrix of parameters, $x_{t}$ is a $k \times 1$ vector of independent variables, which contains, following the results obtained in the univariate analysis, first lags of the returns $r_{t-1}, H_{t}^{1 / 2}$ is the Cholesky factor of the time varying conditional covariance matrix of the disturbances $H_{t}$ and $v_{t}$ is a $m \times 1$ vector of i.i.d. innovations with zero mean and unit variance. As $i=1, \ldots, 9$ we would ideally consider a multivariate GARCH model where $m=$ 9.

In the conditional correlation family of multivariate GARCH models, the diagonal elements of $H_{t}$ are modelled as univariate GARCH models, whereas the off-diagonal elements are modelled as nonlinear functions of the diagonal terms:

$$
h_{i j t}=\rho_{i j} \sqrt{h_{i i t} h_{i j t}}
$$

The constant conditional correlation (CCC) model assumes that the diagonal elements $h_{i t}$ and $h_{j j t}$ follow a univariate GARCH processes and $\rho_{i j}$ is a time-invariant weight interpreted as a conditional correlation. In other words, conditional correlations among returns are constant over time.

Formally, this implies that matrix $H_{t}$ is modelled as: 


$$
H_{t}=D_{t}^{1 / 2} R D_{t}^{1 / 2}
$$

where $D_{t}$ is a diagonal matrix of conditional variances in which each $\sigma_{i t}^{2}$ evolves according to a univariate GARCH process defined as in the univariate analysis as $\sigma_{i t}^{2}=s_{i}+\sum_{j=1}^{p_{i}} \alpha_{j} \varepsilon_{i t-j}^{2}+\sum_{j=1}^{q_{i}} \beta_{j} \sigma_{i t-j}^{2}$ (again we will present the results specifying $p=q=1$ ) and $R$ is a matrix of time-invariant unconditional correlations of the standardized residuals $D_{t}^{-1 / 2} \varepsilon_{t}$.

While the constant conditional correlation assumption allows to estimate large systems as it reduces the number of parameters to be estimated, several studies on crude oil returns have shown that this hypothesis is unrealistic as conditional correlations are generally found to be time varying (Lanza et al. 2006, Manera et al. 2006, Chang et al. 2009, 2010). Indeed, as will be shown in the next section, this hypothesis does not fit our data, both in energy and agricultural markets.

Therefore, we present the results obtained with the dynamic conditional correlation (DCC) model, which drops the latter assumption. More precisely, the diagonal elements $h_{i i t}$ and $h_{j j t}$ in (4) still follow a univariate GARCH processes while $\rho_{i j}$ now follows a dynamic process (Engle 2002).

Formally, the $D_{t}$ matrix in (3.c) is defined as before, while the $R_{t}$ matrix is now defined as:

$$
\begin{aligned}
& R_{t}=\operatorname{diag}\left(Q_{t}\right)^{-1 / 2} Q_{t} \operatorname{diag}\left(Q_{t}\right)^{-1 / 2} \\
& Q_{t}=\left(1-\lambda_{1}-\lambda_{2}\right) R+\lambda_{1} \widetilde{\varepsilon}_{t-1} \widetilde{\varepsilon}_{t-1}^{\prime}+\lambda_{2} Q_{t-1}
\end{aligned}
$$

where $R_{t}$ is a matrix of time-varying conditional quasicorrelations, $\widetilde{\varepsilon}_{t}$ is an $\mathrm{m} \times 1$ vector of standardized residuals $\left(D_{t}^{-1 / 2} \varepsilon_{t}\right)$ and $\lambda_{1}$ and $\lambda_{2}$ are the two parameters that determine the dynamics of conditional quasicorrelations. They are both non-negative, and they must satisfy the condition $0 \leq \lambda_{1}+\lambda_{2}<1$. When $Q_{t}$ is stationary, the $R$ matrix is a weighted average of the unconditional covariance matrix of the standardized residuals $\widetilde{\varepsilon}_{t}$ and the unconditional mean of $Q_{t}$. As the two matrices are different, the $R$ matrix is neither the unconditional correlation matrix, nor the unconditional mean of $Q_{t}$. As a consequence, the parameters in $R$ are known as quasicorrelations (Engle 2009).

A minor shortcoming of this model is that the complexity involved, in terms of number of coefficients to be estimated, might imply some problems in the maximization of the likelihood function. 
As a consequence, we present our results dividing the commodities into two subgroups. In the first one, which we label "fuels", we include the four energy commodities and the soybean oil: in this way, we are able to investigate possible spillovers between energy markets and a biofuel.

The second one includes the five agricultural commodities: this allows to test the presence of spillovers between food commodities and a biofuel, which has been proposed in the literature (Mitchell 2008, FAO 2009).

Indeed, several authors suggests that spillovers might be present between energy and agricultural markets as well (Mitchell 2008, Baffes 2007, 2009, Du et al. 2011, Baffes and Haniotis 2010). To test this hypothesis, we extend the second system of equations (i.e. "agricultural" commodities) by including a sixth endogenous variable. We could include returns in crude oil market to investigate if and how energy markets influence agricultural commodities. It has been highlighted however that other energy commodities are relevant in the formation of agricultural prices. For example, natural gas is the basis for nitrogen fertilizer production. As a consequence, we prefer to summarize dynamics in energy futures markets by means of a principal factor analysis. Notice that the factor is constructed using information contained in the four purely "energy" commodities, i.e. not including soybean oil. As a consequence, the latter system allows to separately consider the spillover between energy markets, a biofuel and food commodities.

\section{Results}

Estimation results for the univariate specification are shown in Table 5. For all the commodities, the Lagrange multiplier test for ARCH effects indicates the presence of $\mathrm{ARCH}$ effects in the residuals of the OLS estimate of the model. Thus, we move to a $\operatorname{GARCH}(1,1)$ specification. Additionally, the Ljung-Box test (not reported) on the $\operatorname{GARCH}(1,1)$ model shows that the residuals contain autocorrelation up to order 1 . However, introducing an $\mathrm{AR}(1)$ term in the models eliminates autocorrelation of the residuals, as shown by the Ljung-Box test reported.

The speculation index is negative or not significant. This result contrasts with claims that speculation has affected returns in a positive way. A negative sign implies that an increase in excess speculations corresponds to a decrease in returns.

As for the macroeconomic controls in the models, we observe that the S\&P 500 index is positive and generally significant, and that the exchange rate is negative and generally significant, suggesting that a depreciation of U.S. dollar compared to other currencies increases futures prices 
and is thus correlated with positive returns. ${ }^{13}$ As expected, the ARCH $(\alpha)$ and $\operatorname{GARCH}(\beta)$ terms are always statistically significant: the ARCH estimates are generally small (between 0.072 for soybean oil and 0.173 for soybeans) and the GARCH estimates are generally high and close to one (between 0.741 for heating oil and 0.892 for wheat). This indicates a near long memory process: a shock in the volatility series impacts on futures volatility over a long horizon. Notice however that as $\alpha+\beta<1$ for all commodities, the second moment and log-moment conditions are satisfied in all markets, and this is a sufficient condition for consistency and asymptotic normality of the QMLE estimator (McAleer at al. 2007).

To analyze the spillovers between different commodities and the linkages between different futures markets we move to a system where the returns are jointly estimated, allowing for conditional variances. In this way it is possible to investigate, for example, if gasoline or natural gas returns are affected or affect oil returns, or if returns of agricultural commodities are affected by energy returns. Additionally, we may check if the speculation index of one commodity influences returns of other ones.

Starting from a $\operatorname{GARCH}(1,1)-\mathrm{AR}(1)$ specification that is supported for all commodities in the univariate case, we consider a CCC multivariate GARCH and we compare it with a DCC model. The latter model is the preferred specification, as the conditional correlations obtained are clearly not constant over time (more infra). In each equation the returns of each commodity are regressed on the macroeconomics controls, on the lagged dependent variable ${ }^{14}$ and on the lagged returns of the other commodities. Finally, we include among the regressors the own speculative index as well as the Working's $\mathrm{T}$ of all the other commodities, to investigate if speculation in one market is significant in other markets.

The results for the group of "fuels" commodities are presented in Tables from 6.a to 7.b. Table 6.a reports the results for the $\mathrm{CCC}$ model. Among macroeconomic variables, the S\&P index is always positive and significant and the exchange rate is generally negative and significant. We mainly observe, with the exception of heating oil, that lagged values of the dependent variable are positive and significant, suggesting persistence in returns. Moreover, lagged returns in crude oil and natural gas positively affect returns of the other commodities. The estimates suggest that speculation is widely not significant: the Working's $\mathrm{T}$ index in own markets is generally negative, confirming the results obtained in the univariate analysis. The $\mathrm{ARCH}(\alpha)$ and $\mathrm{GARCH}(\beta)$ terms are always positive and statistically significant and their sum is smaller than one. Again, the ARCH estimates

\footnotetext{
${ }^{13}$ As noted before some authors suggest that causality between exchange rate and returns could run in both directions. We replicate the whole set of results omitting exchange rate among the regressors. The results concerning the other regressors are unaffected.

${ }^{14}$ We include only one lag as the univariate case supports an AR(1) model.
} 
are typically small and the GARCH estimates are generally high, confirming the presence of a near long memory process. We estimate the models assuming a multivariate Student's T distribution for the error terms. The degrees of freedom of the distribution are estimated and reported at the bottom of Table 6.a.

Table 6.b presents the constant conditional correlations among commodities: they are all positive and statistically significant at $1 \%$ level. The highest is the one between crude oil and heating oil (0.815). Notice however that, albeit smaller in size, positive and statistically significant at $1 \%$ correlations exist between soybean oil and the other energy commodities.

Table 7.a reports the results obtained with the DCC specification. Notice that the DCC model reduces to the $\mathrm{CCC}$ if the $\lambda$ parameters are both equal to zero. We test the null hypothesis that $\lambda_{1}=\lambda_{2}=0$ : the test strongly rejects the null, thus supporting the dynamic specification. Results of DCC model confirm those of CCC. Among macroeconomic factors, S\&P and exchange rate are significant. Own lagged returns are generally significant and the same holds for lagged returns of crude oil and natural gas. Again speculation is poorly significant.

Moreover, the DCC model allows to retrieve the time-varying conditional correlations, which are plotted in Figure 2.a: the graphs clearly show that the correlations are time-varying. Interestingly, the correlations between soybean oil and the other energy commodities present high values around the year 2008, i.e. in the peak period of prices (see Figure 1). Descriptive statistics on the conditional correlations are reported in Table 7.b. Albeit on average slightly smaller than the correlations obtained in the CCC model, the dynamic conditional correlations confirm the results reported in Table 6.b: the highest mean values observed is between heating oil and crude oil (0.773) followed by the one between gasoline and crude oil (0.723) and between gasoline and heating oil (0.706). The lowest mean values are those related to soybean oil. Besides, all the correlations vary dramatically displaying also negative values and having a large range of variation. For example, if we consider the correlation between heating oil and crude oil, a maximum value of 0.875 means that, on the corresponding week $\left(13^{\text {th }}\right.$ week of 1998), heating oil and crude oil returns would have brought almost the same risk, so that investing in the futures market and choosing between one of them, brings the same risk. On the contrary, a minimum value of -0.206 ( $50^{\text {th }}$ week of 2000$)$ between natural gas and crude oil means that shocks to these two commodities are not perfect substitutes in terms of risk. Finally, skewness and kurtosis values indicate negatively skewed distributions in the majority of correlations.

Results for the "agriculture" group of commodities are reported in Tables 8.a-9.b. Again, the CCC and DCC provide similar results. Among macroeconomic controls, only the S\&P return and the exchange rate display significant coefficients, with the expected signs. We do not observe spillovers 
in the mean equation: only the own lagged return shows positive and significant coefficients. Measures of speculation are poorly significant: the Working's $\mathrm{T}$ index of corn and soybean oil are generally negative and significant.

The conditional correlations implied by the CCC model reported in Table 8.b are generally high and statistically significant. Similar results are found in the dynamic conditional correlations, plotted in Figure 2.b. Notice that, contrary to the "fuels" DCC, we do not observe marked peaks in recent times. The minimum values of the correlations reported in Table 9.b are, within this group, always positive, meaning that the substitution effect in risk is absent in these futures markets.

Finally, we discuss the results for the extended group, which includes agricultural commodities and a factor summarizing the four energy variables, which has been obtained using the principal factor method to analyze the correlation matrix among the returns of the four energy commodities. Results reported in Tables 10.a-11.b confirm previous evidence concerning the five agricultural commodities. However, we observe no evident spillover in the mean equation among food commodities, a biofuel and the energy factor.

The constant conditional correlations, reported in Table 10.b, are generally positive and significant. Interestingly, the correlations between the energy factor and the other commodities are generally low, with the highest value being the correlation with soybean oil (0.134). Figure 2.c reports the dynamic conditional correlations, and shows that, while being on average small, the conditional correlations with the energy factor display a peak around year 2008. The descriptive statistics reported in Table 11.b for the DCC show that negative and significant values exist, only when considering correlations with the energy factor. This last result confirms that spillovers between energy and agriculture commodities exist: negative correlations indicate that high volatility values in the energy markets correspond to low volatility levels in the markets for agricultural commodities.

\subsection{Sensitivity over time}

Our sample has a long time span, so it is interesting to see if spillover effects in the volatility of commodity returns become more marked in recent years. This is shown in Table 12.a, where are reported mean tests on dynamic conditional correlations of "fuels" group. All the t-statistics are significant at $1 \%$ level, meaning that mean values are statistically different in the two samples. In particular, values after 2004 are higher than those in the 1990-2003 period and mean values between energy commodities and soybean oil are almost doubled in the second period. This result confirms the increasing interaction between markets, especially when biofuels are considered. Table 12.b shows that, also for the "agriculture" group, mean values are increased after 2004, but, this 
time, the increase is less evident and the relationship with biofuels is less marked. Finally, Table 12.c confirms that, also in this last group, mean values of dynamic conditional correlations between agricultural commodities and the energy factor are doubled or more than doubled after 2004.

It is also interesting to see if there are changes in mean equations before and after 2004 and, in general, in the results of CCC and DCC estimations. ${ }^{15}$ As regards the "fuels" group it is relevant to notice that the influence of crude oil (with reference to its past returns and its Working's T index) on other commodities and, in particular, on soybean oil, appears to be significant only after 2004, suggesting that spillovers in the mean equation happen mostly in the last period. Interestingly, we find that the conditional correlations increase in size after 2004 and that the correlations between fuels and soybean oil become significant and positive, confirming again spillover effects in recent times. Results for the "agriculture" group, both in CCC and DCC models, do not show marked differences before and after 2004. Finally, looking at the "agriculture" system enriched with the energy factor, we observe that the correlations between the energy factor and the agricultural commodities and biofuel become significant only after 2004. These last results support once again the increasing interaction between different markets and are in line with similar results obtained adopting alternative econometric approaches (Natanelov et al. 2011, Ciaian and Kancs 2011).

\section{Conclusions}

The recent spike in commodities prices in 2008 has lead to claims that prices are driven by speculators. Moreover, as the rise has affected both energy and food commodities a generalized financialization of commodities futures markets has been held responsible. Another channel for the transmission of price shocks has been alleged to be the increasing relevance of biofules, which interconnect energy and food markets. However, most of the evidence in support of these hypotheses is based on descriptive statistics.

We collect data on futures prices for four energy commodities (light sweet crude oil, heating oil, gasoline and natural gas) and five agricultural commodities (corn, oats, soybean oil, soybeans and wheat) over the period 1986-2010 at weekly frequency and measure financial speculation by means of the Working's T (1960) index. With this sample we aim at answering to four research questions. First, we look at the role of macroeconomic factors as possible drivers of returns of energy and nonenergy commodities. Secondly, we consider whether financial speculation is significantly related to returns in futures markets. Finally, we focus on the relationship among returns across different

\footnotetext{
${ }^{15}$ These results are reported in the Statistical Appendix, which is available from the authors upon request.
} 
markets both with respect to the mean and the variance. Moreover, we investigate if and how speculation in one market affects returns in other markets.

Descriptive evidence shows that the Working's T index has significantly increased after 2004 only in crude oil, natural gas and wheat futures markets. Additionally, if we look at the correlations with commodities returns, Working's T indexes are in almost all cases not significant, suggesting a weak relationship between speculation in different markets.

The econometric exercise presents an univariate analysis where commodity returns are modelled according to a $\operatorname{GARCH}(1,1)$ with an $\mathrm{AR}(1)$ term. Working's $\mathrm{T}$ index is always negative or not significant: a negative sign implies that an increase in excess speculation corresponds to a decrease in returns. This result contrasts with the claims in the literature that speculation has affected returns in a positive way (Eckaus 2008, Masters 2008, Soros 2008). Among macroeconomic factors, S\&P500 index is positive and significant and the exchange rate is negative and generally significant, suggesting that a depreciation of U.S. dollar increases futures prices.

To analyze spillovers between commodities and different futures markets we present results from multivariate GARCH models. We group the commodities into two subgroups, "fuels" (gasoline, heating oil, natural gas, crude oil and soybean oil) and "agriculture" (corn, oats, soybeans, wheat and soybean oil) and we estimate a system where returns are jointly estimated, allowing for conditional correlations. The multivariate-GARCH DCC model is always preferred to the CCC, as the conditional correlations obtained are not constant over time. As in the univariate case, S\&P500 index is always positive and significant and the exchange rate is generally negative and significant. Thus, as concerns our first research question, few macroeconomic variables seems to significantly affect the returns in commodities futures: the S\&P index and the multilateral exchange rate. As regard our second research question, estimates suggest that speculation is generally not relevant. However, when including an energy factor in the "agriculture" group, we find an interesting result: Working's $\mathrm{T}$ index in crude oil market assumes a positive and significant effect on soybean oil returns after 2004, indicating a linkage between energy markets and a biofuel one in recent times.

As for the third issue, i.e. possible spillovers across commodities, both in the mean and variance equation, we observe that lagged returns of crude oil and natural gas positively affect returns of the other energy commodities. Looking at volatilities, it is interesting to note that correlations between soybean oil and the other energy commodities and those between agricultural and energy factor present high values around 2008, i.e. in the peak period of prices. Moreover, when we distinguish between time periods, we notice that: (i) mean values of dynamic conditional correlations always increase after 2004 and, in fuels markets, they even double; (ii) conditional correlations and quasicorrelations between commodities in these two groups become significant and positive only in 
the second period. Spillover effects are also detected in the correlations between agriculture and energy factor: negative correlations suggest that high volatility in one market corresponds to low volatility in the other.

\section{References}

Ai, Chunrong, Arjun Chatrath and Frank Song. 2006. "On the Comovement of Commodity Prices" American Journal of Agricultural Economics 88 (3): 574-588.

Baffes, John. 2007. “Oil spills on other commodities” Resources Policy 32 (3): 126-134.

Baffes, John. 2009. "More on the Energy/Non-Energy Commodity Price Link" World Bank Policy Research Working Paper No. 4982.

Baffes, John and Tassos Haniotis. 2010. "Placing the 2006/08 Commodity Price Boom into Perspective” Policy Research Working Paper 5371.

Brunetti, Celso, and Bahattin Büyükşahin. 2009. Is Speculation Destabilizing? U.S. Commodity Futures Trading Commission Working Paper.

Büyükşahin, Bahattin and Jeffrey H. Harris. 2011. "Do Speculators Drive Crude Oil Futures Prices?” The Energy Journal 32 (2): 167-202.

Cashin, Paul A., John C. McDermott and Alasdair M. Scott. 1999. "The Myth of Co-moving Commodity Prices” Reserve Bank of New Zealand, Discussion Paper Series No. G99/9.

Chang, Chia-Lin, Michael McAleer and Roengchai Tansuchat. 2009. "Modeling conditional correlations for risk diversification in crude oil markets" Journal of Energy Markets 2: 29-51.

Chang, Chia-Lin, Michael McAleer and Roengchai Tansuchat. 2010. "Analyzing and forecasting volatility spillovers, asymmetries and hedging in major oil markets" Energy Economics 32: 14451455.

Chang, Chia-Lin, Michael McAleer and Roengchai Tansuchat. 2011. "Crude oil hedging strategies using dynamic multivariate GARCH” Energy Economics 33: 912-923.

Chaudhuri, Kausik. 2001. "Long-run prices of primary commodities and oil prices" Applied Economics 33 (4): 531-538.

Chen, Yu-Chin, Kenneth S. Rogoff and Barbara Rossi. 2010. "Can exchange rate forecast commodity prices?" Quarterly Journal of Economics 125 (3): 1145-1194. 
Chevallier, Julien. 2009. "Carbon Futures and Macroeconomic Risk Factors: a View from the EU ETS” Energy Economics 31: 614-625.

Ciaian, Pavel and d'Artis Kancs. 2011. "Food, energy and environment: Is bioenergy the missing link?" Food Policy 36: 571-580.

Deb, Partha, Pravin K. Trivedi and Panayotis Varangis. 1996. "The Excess Co-Movement of Commodity Prices Reconsidered" Journal of Applied Econometrics 11 (3): 275-291.

Du, Xiaodong, Cindy L. Yu and Dermot J. Hayes. 2011. "Speculation and volatility spillover in the crude oil and agricultural commodity markets: A Bayesian analysis" Energy Economics 33: 497-503.

Eckaus, Richard S. 2008. "The Oil Price Really Is A Speculative Bubble” Center for Energy and Environmental Policy Research 08-007.

Engle, Robert F. 2002. "Dynamic conditional correlation: A simple class of multivariate generalized autoregressive conditional heteroskedasticity models" Journal of Business \& Economic Statistics 20 (3): 339-350.

Engle, Robert F. 2009. Anticipating Correlations A New Paradigm for Risk Management. Princeton, NJ: Princeton University Press.

Food and Agriculture Organization of the United Nations (FAO). 2009. The State of Agricultural Commodity Markets: High Food Prices and the Food Crisis - Experiences and Lessons Learned.

Frankel, Jeff A. 2008a. "The Effect of Monetary Policy on Real Commodity Prices" in "Asset Prices and Monetary Policy” John Y. Campbell (Ed.), 291 - 333.

Frankel, Jeff A. 2008b. "Commodity Prices, Again: Are Speculators to Blame?" http://content.ksg.harvard.edu/blog/jeff_frankels_weblog/2008/07/25/commodity-prices-again-arespeculators-to-blame.

Gilbert, Christopher L. 2010. "How to Understand High Food Prices" Journal of Agricultural Economics 61 (2): 398-425.

Granger, Clive W. J. 1986. "Developments in the Study of Cointegrated Economic Variables" Oxford Bulletin of Economics and Statistics 48: 213-228.

Irwin, Scott H. and Dwight R. Sanders. 2012. "Testing the Masters Hypothesis in commodity futures markets" Energy Economics 34: 256-269.

Kaufmann, Robert K. and Ben Ulman. 2009. "Oil prices, speculation, and fundamentals: Interpreting causal relations among spot and futures prices" Energy Economics 31: 550-558. 
Kaufmann, Robert K. 2011. "The role of market fundamentals and speculation in recent price changes for crude oil” Energy Policy 39: 105-115.

Khan, Moshin S. 2009. "The 2008 Oil Price "Bubble"” Peterson Institute for International Economics No. PB09-19.

Lanza, Alessandro, Matteo Manera and Michael McAleer. 2006. "Modeling dynamic conditional correlations in WTI oil forward and future returns" Finance Research Letters 3 (2): 114-132.

LeyBourne, Stephen J., Tim A. Lloyd and Geoffrey V. Reed. 1994. “The Excess Comovement of Commodity Prices Revisited" World Development 22 (11): 1747-1758.

Malliaris, Anastasios G. and Jorge L. Urrutia. 1996. "Linkages Between Agricultural Commodity Futures Contracts" Journal of Futures Markets 16 (5): 595-609.

Manera, Matteo, Michael McAleer and Margherita Grasso. 2006. "Modeling time-varying conditional correlations in the volatility of Tapis oil spot and forward returns" Applied Financial Economics 16 (7): 525-533.

Masters, Michael W. 2008. "Testimony of Michael W. Masters before the Committee on Homeland Security and Governmental Affairs United States Senate”, May 2008. http://hsgac.senate.gov/public/_files/052008Masters.pdf.

McAleer, Michael, Felix Chan and Dora Marinova. 2007. "An econometric analysis of asymmetric volatility: theory and application to patents" Journal of Econometrics 139 (2): 259-284.

Medlock III, Kenneth B. and Amy M. Jaffe. 2009. "Who Is In the Oil Futures Market and How Has It Changed?” James A. Baker III Institute for Public Policy, Rice University.

Mitchell, Donald. 2008. “A Note on Rising Food Prices” Policy Research Working Paper No. 4682.

Natanelov, Valeri, Mohammad J.Alam, Andrew M. McKenzie and Guido Van Huylenbroeck. 2011. "Is there co-movement of agricultural commodities futures prices and crude oil?" Energy Policy 39: 4971-4984.

Palaskas, Theodosios B. and Panos N. Varangis. 1991. "Is There Excess Co-Movement of Primary Commodity Prices?” Working Paper World Bank WPS 758.

Pindyck, Robert S. and Julio J. Rotemberg. 1990. “The Excess Co-Movement of Commodity Prices" The Economic Journal 100 (403): 1173-1189.

Robles, Miguel, Maximo Torero and Joachim von Braun. 2009. "When Speculation Matters" International Food Policy Research Institute, Issue Brief 57. 
Sadorsky, Perry. 2002. "Time-varying Risk Premiums in Petroleum Futures Prices" Energy Economics 24: 539-556.

Sanders, Dwight R., Scott H. Irwin and Robert P. Merrin. 2010. "The Adequacy of Speculation in Agricultural Futures Markets: Too Much of a Good Thing?" Applied Economic Perspectives and Policy 32 (1): 77-94.

Soros, George. 2008. "Testimony before the U.S. Senate Commerce Committee Oversight Hearing on FTC Advanced Rulemaking on Oil Market Manipulation”, June 2008. http://www.georgesoros.com/files/SorosFinal-Testimony.pdf.

Stoll, Hans R. and Robert E. Whaley. 2010. "Commodity Index Investing and Commodity Futures Prices" Journal of Applied Finance 20 (1): 7-46.

Trostle, Ronald. 2008. "Global Agricultural Supply and Demand: Factors Contributing to the Recent Increase in Food Commodity Prices" Report from the Economic Research Service of US Department of Agriculture WRS-0801.

U.S. Energy Information Administration (EIA). 2008. Short Term Energy Outlook, 2008-07.

Vansteenkiste, Isabel. 2009. "How important are common factors in driving non-fuel commodity prices? A dynamic factor analysis” European Central Bank, Working Paper No. 1072.

Verleger, Philip K. 2009. "The Role of Speculators in Setting the Price of Oil”, Testimony to U.S. Commodities Futures Trading Commission. http://www.cftc.gov/ucm/groups/public/@newsroom/documents/file/hearing080509_verleger.pdf.

Working, Holbrook. 1960. "Speculation on Hedging Markets" Food Research Institute Studies $1: 185-220$. 
Tables and Figures

Table 1: Variables description (weekly observations)

\begin{tabular}{cccccc}
\hline \hline & Commodity & Start Date & End Date & $\begin{array}{c}\text { Mnemonic } \\
\text { Datastream }\end{array}$ & $\begin{array}{c}\text { Commodity } \\
\text { Code CFTC }\end{array}$ \\
\hline \multirow{2}{*}{ ENERGY } & Gasoline & $01 / 15 / 1986$ & $12 / 31 / 2010$ & $\begin{array}{c}\text { NHUCS00 and } \\
\text { NRBCS00 }\end{array}$ & 111 \\
& Heating Oil & $06 / 13 / 1986$ & $12 / 31 / 2010$ & NHOCS00 & 022 \\
& Natural Gas & $04 / 12 / 1990$ & $12 / 31 / 2010$ & NNGCS00 & 023 \\
& Crude Oil & $01 / 15 / 1986$ & $12 / 31 / 2010$ & NCLCS00 & 067 \\
\hline \multirow{3}{*}{ AGRICULTURE } & Soybean oil & $01 / 15 / 1986$ & $12 / 31 / 2010$ & CBOCS00 & 007 \\
& Corn & $01 / 15 / 1986$ & $12 / 31 / 2010$ & CC.CS00 & 002 \\
& Oats & $01 / 15 / 1986$ & $12 / 31 / 2010$ & CO.CS00 & 004 \\
& Soybeans & $01 / 15 / 1986$ & $12 / 31 / 2010$ & CS.CS00 & 005 \\
\hline \hline
\end{tabular}

Notes: For each commodity we retrieved settlement price (U\$) from Datastream and open interest (no. contracts) from CFTC. For gasoline we have employed unleaded gasoline from January 1986 to December 2006 and Reformulated Blendstock for Oxygenate Blending (RBOB) gasoline from February 2006 to December 2010. For the period February-December 2006, when both types are available, prices are given by the sample average of the two price series, while we sum open interest series. 
Table 2: Summary statistics on weekly observations

\begin{tabular}{|c|c|c|c|c|c|c|}
\hline & Obs & Mean & Std. Dev. & Min & Max & Unit Root Test \\
\hline \multicolumn{7}{|c|}{ FUTURES PRICES } \\
\hline Gasoline & 1299 & 0.970 & 0.640 & 0.318 & 3.538 & -0.737 \\
\hline Heating Oil & 1279 & 0.960 & 0.689 & 0.302 & 4.039 & -0.403 \\
\hline Natural Gas & 1079 & 4.056 & 2.563 & 1.100 & 14.462 & -2.098 \\
\hline Crude Oil & 1298 & 34.292 & 24.520 & 11.048 & 142.800 & -0.294 \\
\hline Soybean Oil & 1299 & 0.249 & 0.090 & 0.134 & 0.670 & 0.192 \\
\hline Corn & 1299 & 2.721 & 0.899 & 1.439 & 7.473 & -0.386 \\
\hline Oats & 1299 & 1.734 & 0.630 & 0.957 & 4.591 & -1.121 \\
\hline Soybeans & 1299 & 6.759 & 2.057 & 4.211 & 16.279 & -0.647 \\
\hline Wheat & 1299 & 4.033 & 1.494 & 2.376 & 12.682 & -0.860 \\
\hline \multicolumn{7}{|c|}{ RETURNS } \\
\hline Gasoline & 1298 & 0.001 & 0.046 & -0.183 & 0.253 & $-30.778 * * *$ \\
\hline Heating Oil & 1278 & 0.001 & 0.041 & -0.181 & 0.199 & $-30.293 * * *$ \\
\hline Natural Gas & 1078 & 0.001 & 0.061 & -0.215 & 0.255 & $-27.278 * * *$ \\
\hline Crude Oil & 1297 & 0.001 & 0.043 & -0.213 & 0.199 & $-31.352 * * *$ \\
\hline Soybean Oil & 1298 & 0.001 & 0.028 & -0.154 & 0.138 & $-28.171 * * *$ \\
\hline Corn & 1298 & 0.001 & 0.031 & -0.178 & 0.199 & $-29.192 * * *$ \\
\hline Oats & 1298 & 0.001 & 0.040 & -0.146 & 0.243 & $-29.659 * * *$ \\
\hline Soybeans & 1298 & 0.001 & 0.028 & -0.156 & 0.124 & $-29.086 * * *$ \\
\hline Wheat & 1298 & 0.001 & 0.029 & -0.148 & 0.142 & $-29.488 * * *$ \\
\hline \multicolumn{7}{|c|}{ WORKING'S T } \\
\hline Gasoline & 1299 & 1.105 & 0.046 & 1.036 & 1.386 & $-5.667 * * *$ \\
\hline Heating Oil & 1279 & 1.154 & 0.051 & 1.050 & 1.340 & $-5.550 * * *$ \\
\hline Natural Gas & 1079 & 1.128 & 0.083 & 1.021 & 1.517 & $-4.304 * * *$ \\
\hline Crude Oil & 1298 & 1.140 & 0.039 & 1.051 & 1.278 & $-5.097 * * *$ \\
\hline Soybean Oil & 1299 & 1.183 & 0.065 & 1.051 & 1.364 & $-6.806 * * *$ \\
\hline Corn & 1299 & 1.250 & 0.047 & 1.146 & 1.401 & $-5.366^{* * *}$ \\
\hline Oats & 1299 & 1.180 & 0.091 & 1.040 & 1.592 & $-5.608 * * *$ \\
\hline Soybeans & 1299 & 1.268 & 0.068 & 1.113 & 1.492 & $-5.063 * * *$ \\
\hline Wheat & 1299 & 1.194 & 0.053 & 1.028 & 1.404 & $-6.714 * * *$ \\
\hline \multicolumn{7}{|c|}{ MACROECONOMIC VARIABLES } \\
\hline T-bill & 1300 & 4.087 & 2.198 & 0.020 & 9.033 & -0.448 \\
\hline Dlog(T-bill) & 1299 & -0.003 & 0.083 & -0.787 & 0.799 & $-26.943 * * *$ \\
\hline S\&P 500 & 1300 & 826.488 & 416.504 & 206.274 & 1559.282 & -1.131 \\
\hline Dlog(S\&P 500) & 1299 & 0.001 & 0.020 & -0.178 & 0.096 & $-30.260 * * *$ \\
\hline Junk Bond Yield & 1300 & 0.984 & 0.412 & 0.520 & 3.456 & -2.042 \\
\hline Dlog(Junk Bond Yield $)$ & 1299 & -0.001 & 0.036 & -0.170 & 0.381 & $-26.701 * * *$ \\
\hline Exchange Rate & 1300 & 90.490 & 9.943 & 69.590 & 120.960 & -2.556 \\
\hline Dlog(Exchange Rate $)$ & 1299 & -0.001 & 0.008 & -0.041 & 0.034 & $-27.801 * * *$ \\
\hline
\end{tabular}

Notes: "Unit Root Test" reports the Augmented Dickey-Fuller statistics for the null hypothesis that there is a unit root in the variable. $* * *, * *$ and $*$ denote significance at $1 \%, 5 \%$ and $10 \%$ levels, respectively. 
Table 3: Summary statistics on Working's $T$ index

\begin{tabular}{|c|c|c|c|c|c|c|c|c|c|c|c|}
\hline \multirow{2}{*}{\multicolumn{2}{|c|}{ Commodity }} & \multicolumn{2}{|c|}{ Obs } & \multicolumn{2}{|c|}{ Mean } & \multicolumn{2}{|c|}{ Std. Dev. } & \multicolumn{2}{|c|}{ Min } & \multicolumn{2}{|c|}{$\operatorname{Max}$} \\
\hline & & $1986-2003$ & $2004-2010$ & $1986-2003$ & $2004-2010$ & $1986-2003$ & $2004-2010$ & $1986-2003$ & $2004-2010$ & $1986-2003$ & 2004-2010 \\
\hline \multirow{4}{*}{ ENERGY } & Gasoline & 935 & 364 & 1.116 & 1.076 & 0.049 & 0.020 & 1.036 & 1.042 & 1.386 & 1.155 \\
\hline & Heating Oil & 915 & 364 & 1.161 & 1.136 & 0.053 & 0.039 & 1.050 & 1.072 & 1.340 & 1.259 \\
\hline & Natural Gas & 715 & 364 & 1.084 & 1.213 & 0.044 & 0.075 & 1.021 & 1.097 & 1.517 & 1.478 \\
\hline & Crude Oil & 935 & 363 & 1.135 & 1.150 & 0.043 & 0.027 & 1.051 & 1.090 & 1.278 & 1.232 \\
\hline \multirow{5}{*}{ AGRICULTURE } & Soybean Oil & 935 & 364 & 1.203 & 1.133 & 0.058 & 0.053 & 1.051 & 1.054 & 1.364 & 1.267 \\
\hline & Corn & 935 & 364 & 1.262 & 1.219 & 0.043 & 0.043 & 1.172 & 1.146 & 1.401 & 1.319 \\
\hline & Oats & 935 & 364 & 1.193 & 1.146 & 0.093 & 0.076 & 1.053 & 1.040 & 1.592 & 1.435 \\
\hline & Soybeans & 935 & 364 & 1.288 & 1.217 & 0.065 & 0.047 & 1.113 & 1.113 & 1.492 & 1.327 \\
\hline & Wheat & 935 & 364 & 1.181 & 1.225 & 0.044 & 0.061 & 1.028 & 1.102 & 1.404 & 1.382 \\
\hline
\end{tabular}


Table 4: Correlations between variables

\begin{tabular}{|c|c|c|c|c|c|c|c|c|c|c|}
\hline & & \multicolumn{9}{|c|}{ RETURNS } \\
\hline & & Gasoline & Heating Oil & Natural Gas & Crude Oil & Soybean Oil & Corn & Oats & Soybeans & Wheat \\
\hline \multirow{9}{*}{ 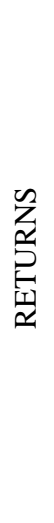 } & Gasoline & 1 & & & & & & & & \\
\hline & Heating Oil & $0.717 * * *$ & 1 & & & & & & & \\
\hline & Natural Gas & $0.229 * * *$ & $0.359 * * *$ & 1 & & & & & & \\
\hline & Crude Oil & $0.735^{* * *}$ & $0.781 * * *$ & $0.242 * * *$ & 1 & & & & & \\
\hline & Soybean Oil & $0.157 * * *$ & $0.177 * * *$ & $0.126 * * *$ & $0.146^{* * *}$ & 1 & & & & \\
\hline & Corn & $0.089 * * *$ & $0.068 * *$ & $0.089 * * *$ & $0.090 * * *$ & $0.493 * * *$ & 1 & & & \\
\hline & Oats & $0.065^{* *}$ & $0.091 * * *$ & $0.068^{* *}$ & $0.082 * * *$ & $0.331 * * *$ & $0.499 * * *$ & 1 & & \\
\hline & Soybeans & $0.139 * * *$ & $0.142 * * *$ & $0.131 * * *$ & $0.128 * * *$ & $0.723 * * *$ & $0.614 * * *$ & $0.350 * * *$ & 1 & \\
\hline & Wheat & $0.103 * * *$ & $0.120 * * *$ & $0.075^{* *}$ & $0.120 * * *$ & $0.315^{* * *}$ & $0.540 * * *$ & $0.379 * * *$ & $0.357 * * *$ & 1 \\
\hline \multirow{9}{*}{ 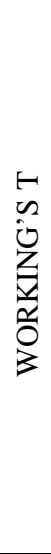 } & Gasoline & $-0.084 * * *$ & -0.023 & 0.031 & $-0.058^{*}$ & $-0.052 *$ & -0.006 & 0.006 & -0.021 & 0.014 \\
\hline & Heating Oil & -0.033 & $-0.068 * *$ & -0.044 & $-0.054 *$ & -0.001 & 0.048 & 0.013 & 0.025 & -0.004 \\
\hline & Natural Gas & -0.021 & -0.032 & $-0.068 * *$ & -0.038 & -0.038 & -0.004 & -0.001 & -0.033 & -0.020 \\
\hline & Crude Oil & -0.001 & 0.016 & -0.017 & 0.012 & -0.009 & 0.010 & -0.003 & -0.015 & -0.019 \\
\hline & Soybean Oil & -0.022 & 0.001 & 0.002 & 0.002 & $-0.108 * * *$ & $-0.065 * *$ & -0.004 & $-0.128 * * *$ & -0.016 \\
\hline & Corn & -0.047 & $-0.073 * *$ & $-0.072 * *$ & -0.041 & -0.025 & $-0.067 * *$ & $-0.072 * *$ & $-0.056^{*}$ & $-0.076^{* *}$ \\
\hline & Oats & 0.032 & 0.039 & 0.035 & 0.038 & -0.006 & -0.004 & 0.015 & -0.037 & -0.030 \\
\hline & Soybeans & -0.035 & -0.029 & -0.044 & -0.030 & $-0.080 * * *$ & -0.033 & -0.022 & $-0.080 * * *$ & -0.015 \\
\hline & Wheat & -0.018 & -0.035 & -0.020 & -0.022 & -0.039 & $-0.054 *$ & -0.006 & -0.042 & -0.046 \\
\hline \multirow{4}{*}{ 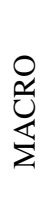 } & Dlog(Tbill) & $0.133 * * *$ & $0.081 * * *$ & 0.025 & $0.098 * * *$ & $0.068^{* *}$ & $0.061 * *$ & -0.007 & $0.082 * * *$ & 0.049 \\
\hline & Dlog(S\&P500) & $0.052^{*}$ & $0.052^{*}$ & 0.047 & $0.060 * *$ & $0.165 * * *$ & $0.134 * * *$ & $0.071 * *$ & $0.141 * * *$ & $0.068 * *$ \\
\hline & Dlog(Junk) & $-0.066 * *$ & -0.042 & 0.020 & $-0.055^{*}$ & $-0.065 * *$ & -0.021 & -0.018 & -0.043 & -0.012 \\
\hline & Dlog(Exchange $)$ & $-0.099 * * *$ & $-0.167 * * *$ & $-0.069 * *$ & $-0.144 * * *$ & $-0.167 * * *$ & $-0.112 * * *$ & $-0.086 * * *$ & $-0.138 * * *$ & $-0.119 * * *$ \\
\hline
\end{tabular}


Table 4: (continued)

\begin{tabular}{|c|c|c|c|c|c|c|c|c|c|c|c|c|c|c|}
\hline & & \multicolumn{9}{|c|}{ WORKING'S T } & \multicolumn{4}{|c|}{ MACRO } \\
\hline & & Gasoline & Heating Oil & Natural Gas & Crude Oil & Soybean Oil & Corn & Oats & Soybeans & Wheat & $\begin{array}{c}\text { Dlog } \\
\text { (Tbill) }\end{array}$ & $\begin{array}{c}\text { Dlog } \\
\text { (S\&P500) } \\
\end{array}$ & $\begin{array}{c}\text { Dlog } \\
\text { (Junk) }\end{array}$ & $\begin{array}{c}\text { Dlog } \\
\text { (Exchange) }\end{array}$ \\
\hline \multirow{9}{*}{ 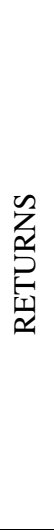 } & Gasoline & & & & & & & & & & & & & \\
\hline & Heating Oil & & & & & & & & & & & & & \\
\hline & Natural Gas & & & & & & & & & & & & & \\
\hline & Crude Oil & & & & & & & & & & & & & \\
\hline & Soybean Oil & & & & & & & & & & & & & \\
\hline & Corn & & & & & & & & & & & & & \\
\hline & Oats & & & & & & & & & & & & & \\
\hline & Soybeans & & & & & & & & & & & & & \\
\hline & Wheat & & & & & & & & & & & & & \\
\hline \multirow{9}{*}{$\begin{array}{l}n \\
n \\
0 \\
z \\
z \\
1 \\
0 \\
0 \\
3\end{array}$} & Gasoline & 1 & & & & & & & & & & & & \\
\hline & Heating Oil & $0.541 * * *$ & 1 & & & & & & & & & & & \\
\hline & Natural Gas & $-0.209 * * *$ & $-0.074 * * *$ & 1 & & & & & & & & & & \\
\hline & Crude Oil & $0.176^{* * *}$ & $0.171 * * *$ & $0.600 * * *$ & 1 & & & & & & & & & \\
\hline & Soybean Oil & $0.333 * * *$ & $0.084 * * *$ & $-0.318 * * *$ & $-0.068 * *$ & 1 & & & & & & & & \\
\hline & Corn & $0.137 * * *$ & $0.102 * * *$ & $-0.269 * * *$ & $-0.050 *$ & $0.401 * * *$ & 1 & & & & & & & \\
\hline & Oats & $-0.147 * * *$ & 0.030 & $-0.115^{* * *}$ & $-0.206^{* * *}$ & $0.058^{*}$ & $0.251 * * *$ & 1 & & & & & & \\
\hline & Soybeans & $0.383^{* * *}$ & $0.339 * * *$ & $-0.295 * * *$ & -0.044 & $0.499 * * *$ & $0.438 * * *$ & 0.017 & 1 & & & & & \\
\hline & Wheat & $-0.103 * * *$ & -0.048 & $0.399 * * *$ & $0.198 * * *$ & -0.036 & $0.066 * * *$ & 0.027 & 0.048 & 1 & & & & \\
\hline \multirow{4}{*}{ 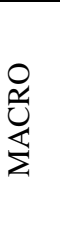 } & Dlog(Tbill) & -0.024 & 0.042 & -0.048 & -0.049 & 0.035 & 0.025 & 0.023 & 0.039 & $-0.050^{*}$ & 1 & & & \\
\hline & $\operatorname{Dlog}(\mathrm{S} \& \mathrm{P} 500)$ & 0.037 & $0.077^{* *}$ & -0.034 & -0.009 & 0.034 & 0.027 & $0.053^{*}$ & $0.055^{*}$ & -0.046 & $0.068 * *$ & 1 & & \\
\hline & Dlog(Junk) & 0.015 & -0.021 & 0.023 & -0.027 & -0.050 & $-0.066^{* *}$ & -0.015 & 0.003 & $0.058^{*}$ & $-0.058 *$ & $-0.175 * * *$ & 1 & \\
\hline & Dlog(Exchange) & 0.012 & 0.014 & 0.022 & -0.019 & 0.047 & -0.008 & -0.024 & $0.067 * *$ & 0.012 & 0.049 & $-0.115^{* * *}$ & $0.080 * * *$ & 1 \\
\hline
\end{tabular}

Notes: * significant at $10 \%$ level, $* *$ significant at $5 \%$ level, $* * *$ significant at $1 \%$ level 
Table 5: Estimates of the univariate specification

\begin{tabular}{|c|c|c|c|c|c|c|c|c|c|c|}
\hline & & Gasoline & Heating Oil & Natural Gas & Crude Oil & Soybean Oil & Corn & Oats & Soybeans & Wheat \\
\hline \multirow{7}{*}{ 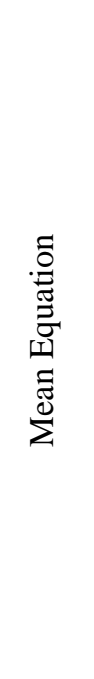 } & Tbill & $\begin{array}{c}0.039 * * \\
(0.015)\end{array}$ & $\begin{array}{c}0.028 * * \\
(0.012)\end{array}$ & $\begin{array}{c}0.016 \\
(0.017)\end{array}$ & $\begin{array}{c}0.022 \\
(0.014)\end{array}$ & $\begin{array}{c}0.013 \\
(0.009)\end{array}$ & $\begin{array}{l}0.018^{*} \\
(0.011)\end{array}$ & $\begin{array}{c}-0.001 \\
(0.012)\end{array}$ & $\begin{array}{c}0.010 \\
(0.010)\end{array}$ & $\begin{array}{c}0.011 \\
(0.011)\end{array}$ \\
\hline & Junk Bond Yield & $\begin{array}{c}-0.050 \\
(0.032)\end{array}$ & $\begin{array}{c}-0.023 \\
(0.027)\end{array}$ & $\begin{array}{c}0.056 \\
(0.050)\end{array}$ & $\begin{array}{c}-0.033 \\
(0.027)\end{array}$ & $\begin{array}{c}-0.012 \\
(0.019)\end{array}$ & $\begin{array}{c}-0.011 \\
(0.021)\end{array}$ & $\begin{array}{c}-0.017 \\
(0.028)\end{array}$ & $\begin{array}{l}-0.021 \\
(0.018)\end{array}$ & $\begin{array}{l}-0.003 \\
(0.019)\end{array}$ \\
\hline & S\&P 500 & $\begin{array}{c}0.068 \\
(0.054)\end{array}$ & $\begin{array}{c}0.106 * * \\
(0.050)\end{array}$ & $\begin{array}{l}0.152^{*} \\
(0.082)\end{array}$ & $\begin{array}{c}0.134 * * * \\
(0.050)\end{array}$ & $\begin{array}{c}0.103 * * * \\
(0.035)\end{array}$ & $\begin{array}{c}0.073 * * \\
(0.036)\end{array}$ & $\begin{array}{c}0.065 \\
(0.049)\end{array}$ & $\begin{array}{c}0.094 * * * \\
(0.033)\end{array}$ & $\begin{array}{c}0.038 \\
(0.036)\end{array}$ \\
\hline & Exchange Rate & $\begin{array}{c}-0.347 * * * \\
(0.134)\end{array}$ & $\begin{array}{c}-0.564 * * * \\
(0.115)\end{array}$ & $\begin{array}{c}-0.135 \\
(0.189)\end{array}$ & $\begin{array}{c}-0.385^{* * *} \\
(0.121)\end{array}$ & $\begin{array}{c}-0.267 * * * \\
(0.089)\end{array}$ & $\begin{array}{l}-0.159^{*} \\
(0.087)\end{array}$ & $\begin{array}{c}-0.268 * * \\
(0.119)\end{array}$ & $\begin{array}{c}-0.197 * * * \\
(0.073)\end{array}$ & $\begin{array}{c}-0.118 \\
(0.084)\end{array}$ \\
\hline & Working's T & $\begin{array}{c}-0.083 * * * \\
(0.029)\end{array}$ & $\begin{array}{c}-0.080 * * * \\
(0.021)\end{array}$ & $\begin{array}{c}-0.057 * * \\
(0.025)\end{array}$ & $\begin{array}{c}0.008 \\
(0.027)\end{array}$ & $\begin{array}{c}-0.052 * * * \\
(0.012)\end{array}$ & $\begin{array}{l}-0.027 \\
(0.018)\end{array}$ & $\begin{array}{l}-0.002 \\
(0.012)\end{array}$ & $\begin{array}{c}-0.026^{* *} \\
(0.010)\end{array}$ & $\begin{array}{l}-0.020 \\
(0.016)\end{array}$ \\
\hline & $\operatorname{AR}(1)$ & $\begin{array}{c}0.179 * * * \\
(0.028)\end{array}$ & $\begin{array}{c}0.161 * * * \\
(0.030)\end{array}$ & $\begin{array}{c}0.199 * * * \\
(0.033)\end{array}$ & $\begin{array}{c}0.156 * * * \\
(0.029)\end{array}$ & $\begin{array}{c}0.208 * * * \\
(0.028)\end{array}$ & $\begin{array}{c}0.201 * * * \\
(0.028)\end{array}$ & $\begin{array}{c}0.174 * * * \\
(0.028)\end{array}$ & $\begin{array}{c}0.201 * * * \\
(0.030)\end{array}$ & $\begin{array}{c}0.209 * * * \\
(0.028)\end{array}$ \\
\hline & Constant & $\begin{array}{c}-0.093 * * * \\
(0.032)\end{array}$ & $\begin{array}{c}0.094 * * * \\
(0.024)\end{array}$ & $\begin{array}{c}0.066^{* *} \\
(0.028)\end{array}$ & $\begin{array}{l}-0.008 \\
(0.031)\end{array}$ & $\begin{array}{c}0.063 * * * \\
(0.014)\end{array}$ & $\begin{array}{c}0.035 \\
(0.022)\end{array}$ & $\begin{array}{c}0.002 \\
(0.014)\end{array}$ & $\begin{array}{c}0.034 * * \\
(0.013)\end{array}$ & $\begin{array}{c}0.024 \\
(0.019)\end{array}$ \\
\hline \multirow{9}{*}{ 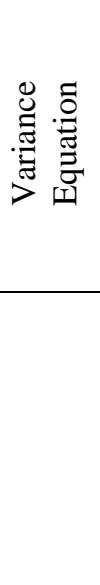 } & $\mathrm{ARCH}(1)$ & $\begin{array}{c}0.114 * * * \\
(0.025)\end{array}$ & $\begin{array}{c}0.166 * * * \\
(0.029)\end{array}$ & $\begin{array}{c}0.153 * * * \\
(0.037)\end{array}$ & $\begin{array}{c}0.130 * * * \\
(0.027)\end{array}$ & $\begin{array}{c}0.072 * * * \\
(0.019)\end{array}$ & $\begin{array}{c}0.151 * * * \\
(0.030)\end{array}$ & $\begin{array}{c}0.115^{* * * *} \\
(0.032)\end{array}$ & $\begin{array}{c}0.173 * * * \\
(0.029)\end{array}$ & $\begin{array}{c}0.087 * * * \\
(0.018)\end{array}$ \\
\hline & GARCH(1) & $\begin{array}{c}0.828 * * * \\
(0.037)\end{array}$ & $\begin{array}{c}0.741 * * * \\
(0.046)\end{array}$ & $\begin{array}{c}0.765 * * * \\
(0.053)\end{array}$ & $\begin{array}{c}0.825 * * * \\
(0.034)\end{array}$ & $\begin{array}{c}0.875 * * * \\
(0.035)\end{array}$ & $\begin{array}{c}0.793 * * * \\
(0.038)\end{array}$ & $\begin{array}{c}0.766 * * * \\
(0.063)\end{array}$ & $\begin{array}{c}0.794 * * * \\
(0.030)\end{array}$ & $\begin{array}{c}0.892 * * * \\
(0.022)\end{array}$ \\
\hline & Constant & $\begin{array}{c}0.000 * * * \\
(0.000)\end{array}$ & $\begin{array}{c}0.000 * * * \\
(0.000)\end{array}$ & $\begin{array}{c}0.000 * * * \\
(0.000)\end{array}$ & $\begin{array}{c}0.000 * * * \\
(0.000)\end{array}$ & $\begin{array}{c}0.000 * * \\
(0.000)\end{array}$ & $\begin{array}{c}0.000 * * * \\
(0.000)\end{array}$ & $\begin{array}{c}0.000 * * * \\
(0.000)\end{array}$ & $\begin{array}{c}0.000 * * * \\
(0.000)\end{array}$ & $\begin{array}{c}0.000 * * \\
(0.000)\end{array}$ \\
\hline & LM test for ARCH & $68.025 * * *$ & $167.973^{* * *}$ & $8.678 * * *$ & $56.957 * * *$ & $29.917 * * *$ & $23.701 * * *$ & $88.460 * * *$ & $30.089 * * *$ & $32.350 * * *$ \\
\hline & Ljung-Box Q test (lag 1) & 2.072 & 0.042 & 0.568 & 0.543 & 0.557 & 0.022 & 0.529 & 0.038 & 0.404 \\
\hline & Log Likelihood & 2286 & 2405 & 1560 & 2402 & 2922 & 2816 & 2442 & 2997 & 2888 \\
\hline & AIC & -4550 & -4788 & -3099 & -4782 & -5821 & -5611 & -4862 & -5971 & -5754 \\
\hline & BIC & -4493 & -4732 & -3044 & -4725 & -5764 & -5554 & -4805 & -5914 & -5698 \\
\hline & N. of Obs. & 1298 & 1278 & 1078 & 1297 & 1298 & 1298 & 1298 & 1298 & 1298 \\
\hline
\end{tabular}

Notes: The error distribution is a Student's T. Standard errors in parentheses. * significant at $10 \%$ level, ** significant at $5 \%$ level, *** significant at $1 \%$ level. 
Table 6.a: CCC model on "fuels" group

\begin{tabular}{|c|c|c|c|c|c|c|}
\hline & & Gasoline & Heating Oil & Natural Gas & Crude Oil & Soybean Oil \\
\hline \multirow{15}{*}{ 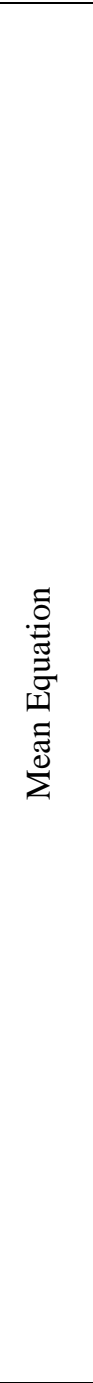 } & Tbill & $\begin{array}{c}0.034 * * \\
(0.015)\end{array}$ & $\begin{array}{c}0.016 \\
(0.013)\end{array}$ & $\begin{array}{c}0.002 \\
(0.019)\end{array}$ & $\begin{array}{c}0.014 \\
(0.014)\end{array}$ & $\begin{array}{c}0.008 \\
(0.011)\end{array}$ \\
\hline & Junk Bond Yield & $\begin{array}{l}-0.051 \\
(0.033)\end{array}$ & $\begin{array}{c}-0.028 \\
(0.028)\end{array}$ & $\begin{array}{c}0.028 \\
(0.047)\end{array}$ & $\begin{array}{l}-0.051 * \\
(0.030)\end{array}$ & $\begin{array}{c}-0.006 \\
(0.020)\end{array}$ \\
\hline & S\&P 500 & $\begin{array}{c}0.179 * * * \\
(0.069)\end{array}$ & $\begin{array}{c}0.185 * * * \\
(0.059)\end{array}$ & $\begin{array}{c}0.181 * * \\
(0.087)\end{array}$ & $\begin{array}{c}0.196 * * * \\
(0.062)\end{array}$ & $\begin{array}{c}0.155 * * * \\
(0.043)\end{array}$ \\
\hline & Exchange Rate & $\begin{array}{c}-0.481 * * * \\
(0.147)\end{array}$ & $\begin{array}{c}-0.636^{* * * *} \\
(0.126)\end{array}$ & $\begin{array}{c}-0.146 \\
(0.210)\end{array}$ & $\begin{array}{c}-0.623 * * * \\
(0.129)\end{array}$ & $\begin{array}{c}-0.370^{* * *} * \\
(0.100)\end{array}$ \\
\hline & Gasoline $(-1)$ & $\begin{array}{c}0.090 * * \\
(0.046)\end{array}$ & $\begin{array}{c}-0.044 \\
(0.037)\end{array}$ & $\begin{array}{c}-0.081 \\
(0.057)\end{array}$ & $\begin{array}{c}-0.011 \\
(0.038)\end{array}$ & $\begin{array}{c}0.028 \\
(0.026)\end{array}$ \\
\hline & Heating Oil(-1) & $\begin{array}{c}-0.139 * * \\
(0.057)\end{array}$ & $\begin{array}{c}-0.044 \\
(0.054)\end{array}$ & $\begin{array}{c}-0.045 \\
(0.073)\end{array}$ & $\begin{array}{c}-0.082 \\
(0.055)\end{array}$ & $\begin{array}{l}-0.017 \\
(0.032)\end{array}$ \\
\hline & Natural Gas(-1) & $\begin{array}{c}0.043 * * \\
(0.020)\end{array}$ & $\begin{array}{c}0.056 * * * \\
(0.018)\end{array}$ & $\begin{array}{c}0.190 * * * \\
(0.034)\end{array}$ & $\begin{array}{c}0.051 * * * \\
(0.018)\end{array}$ & $\begin{array}{c}-0.038 * * * \\
(0.013)\end{array}$ \\
\hline & Crude Oil(-1) & $\begin{array}{c}0.186 * * * \\
(0.058)\end{array}$ & $\begin{array}{c}0.233 * * * \\
(0.051)\end{array}$ & $\begin{array}{c}0.138 * * \\
(0.069)\end{array}$ & $\begin{array}{c}0.198 * * * \\
(0.056)\end{array}$ & $\begin{array}{l}-0.012 \\
(0.032)\end{array}$ \\
\hline & Soybean Oil(-1) & $\begin{array}{l}-0.029 \\
(0.045)\end{array}$ & $\begin{array}{c}-0.068 * \\
(0.038)\end{array}$ & $\begin{array}{c}-0.060 \\
(0.061)\end{array}$ & $\begin{array}{c}-0.073 * \\
(0.039)\end{array}$ & $\begin{array}{c}0.191 * * * \\
(0.032)\end{array}$ \\
\hline & Working's T Gasoline & $\begin{array}{c}-0.112 * * \\
(0.046)\end{array}$ & $\begin{array}{l}-0.000 \\
(0.039)\end{array}$ & $\begin{array}{c}0.083 \\
(0.066)\end{array}$ & $\begin{array}{l}-0.069 * \\
(0.039)\end{array}$ & $\begin{array}{c}0.001 \\
(0.029)\end{array}$ \\
\hline & Working's T Heating Oil & $\begin{array}{c}0.003 \\
(0.031)\end{array}$ & $\begin{array}{c}-0.060 * * \\
(0.027)\end{array}$ & $\begin{array}{c}-0.056 \\
(0.046)\end{array}$ & $\begin{array}{c}-0.032 \\
(0.027)\end{array}$ & $\begin{array}{c}-0.025 \\
(0.021)\end{array}$ \\
\hline & Working's T Natural Gas & $\begin{array}{l}-0.002 \\
(0.021)\end{array}$ & $\begin{array}{c}-0.008 \\
(0.018)\end{array}$ & $\begin{array}{c}-0.059 * * \\
(0.027)\end{array}$ & $\begin{array}{l}-0.015 \\
(0.019)\end{array}$ & $\begin{array}{l}-0.006 \\
(0.014)\end{array}$ \\
\hline & Working's T Crude Oil & $\begin{array}{c}0.018 \\
(0.052)\end{array}$ & $\begin{array}{c}0.045 \\
(0.044)\end{array}$ & $\begin{array}{c}0.045 \\
(0.063)\end{array}$ & $\begin{array}{c}0.061 \\
(0.046)\end{array}$ & $\begin{array}{c}0.021 \\
(0.030)\end{array}$ \\
\hline & Working's T Soybean Oil & $\begin{array}{c}-0.023 \\
(0.019)\end{array}$ & $\begin{array}{l}-0.026 \\
(0.016)\end{array}$ & $\begin{array}{c}-0.068 * * \\
(0.028)\end{array}$ & $\begin{array}{c}-0.026 \\
(0.017)\end{array}$ & $\begin{array}{c}-0.041 * * * \\
(0.012)\end{array}$ \\
\hline & Constant & $\begin{array}{c}0.129 * * \\
(0.057)\end{array}$ & $\begin{array}{c}0.059 \\
(0.050)\end{array}$ & $\begin{array}{c}0.070 \\
(0.078)\end{array}$ & $\begin{array}{l}0.092 * \\
(0.052)\end{array}$ & $\begin{array}{c}0.058^{*} \\
(0.033)\end{array}$ \\
\hline \multirow{9}{*}{ 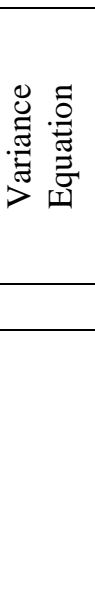 } & $\mathrm{ARCH}(1)$ & $\begin{array}{c}0.081 * * * \\
(0.021)\end{array}$ & $\begin{array}{c}0.090 * * * \\
(0.016)\end{array}$ & $\begin{array}{c}0.134 * * * \\
(0.031)\end{array}$ & $\begin{array}{c}0.104 * * * \\
(0.016)\end{array}$ & $\begin{array}{c}0.126^{* * * *} \\
(0.047)\end{array}$ \\
\hline & GARCH(1) & $\begin{array}{c}0.838 * * * \\
(0.046)\end{array}$ & $\begin{array}{c}0.860 * * * \\
(0.026)\end{array}$ & $\begin{array}{c}0.771 * * * \\
(0.043)\end{array}$ & $\begin{array}{c}0.845^{* * * *} \\
(0.020)\end{array}$ & $\begin{array}{c}0.776^{* * * *} \\
(0.103)\end{array}$ \\
\hline & Constant & $\begin{array}{c}0.000^{* * *} \\
(0.000)\end{array}$ & $\begin{array}{c}0.000 * * * \\
(0.000)\end{array}$ & $\begin{array}{c}0.000 * * * \\
(0.000)\end{array}$ & $\begin{array}{c}0.000^{* * * *} \\
(0.000)\end{array}$ & $\begin{array}{c}0.000 \\
(0.000) \\
\end{array}$ \\
\hline & F-stat on Working's T & $16.330 * * *$ & $12.350 * *$ & $9.940 *$ & $16.230 * * *$ & $16.820 * * *$ \\
\hline & Log Likelihood & & & 11091 & & \\
\hline & $\mathrm{AIC}$ & & & -21980 & & \\
\hline & $\mathrm{BIC}$ & & & -21477 & & \\
\hline & Degree of Freedom & & & $\begin{array}{c}9.378 * * * \\
(1.011)\end{array}$ & & \\
\hline & N. of Obs. & 1076 & 1076 & 1076 & 1076 & 1076 \\
\hline
\end{tabular}

Notes: The error distribution is a multivariate Student's T. Standard errors in parentheses. * significant at $10 \%$ level, ** significant at 5\% level, *** significant at $1 \%$ level. 
Table 6.b: Conditional correlations of CCC model on "fuels" group

\begin{tabular}{|c|c|c|c|c|c|}
\hline & Gasoline & Heating Oil & Natural Gas & Crude Oil & Soybean Oil \\
\hline Gasoline & 1 & & & & \\
\hline Heating Oil & $\begin{array}{c}0.719 * * * \\
(0.016)\end{array}$ & 1 & & & \\
\hline Natural Gas & $\begin{array}{c}0.231 * * * \\
(0.031)\end{array}$ & $\begin{array}{c}0.322 * * * \\
(0.029)\end{array}$ & 1 & & \\
\hline Crude Oil & $\begin{array}{c}0.745 * * * \\
(0.015)\end{array}$ & $\begin{array}{c}0.815^{* * * *} \\
(0.011)\end{array}$ & $\begin{array}{c}0.230 * * * \\
(0.031)\end{array}$ & 1 & \\
\hline Soybean Oil & $\begin{array}{c}0.114 * * * \\
(0.032)\end{array}$ & $\begin{array}{c}0.156 * * * \\
(0.032)\end{array}$ & $\begin{array}{c}0.121 * * * \\
(0.032)\end{array}$ & $\begin{array}{c}0.126^{* * * *} \\
(0.032)\end{array}$ & 1 \\
\hline
\end{tabular}

Notes: * significant at $10 \%$ level, $* *$ significant at $5 \%$ level, *** significant at $1 \%$ level. 
Table 7.a: DCC model on "fuels" group

\begin{tabular}{|c|c|c|c|c|c|c|}
\hline & & Gasoline & Heating Oil & Natural Gas & Crude Oil & Soybean Oil \\
\hline \multirow{15}{*}{ 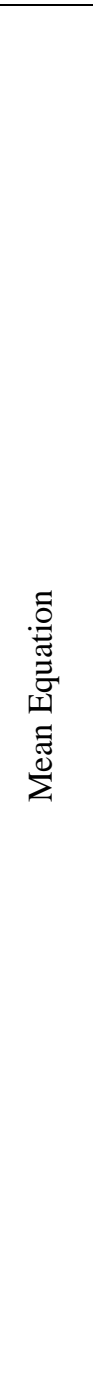 } & Tbill & $\begin{array}{c}0.038 * * \\
(0.016)\end{array}$ & $\begin{array}{c}0.020 \\
(0.013)\end{array}$ & $\begin{array}{c}0.005 \\
(0.018)\end{array}$ & $\begin{array}{c}0.021 \\
(0.015)\end{array}$ & $\begin{array}{c}0.007 \\
(0.011)\end{array}$ \\
\hline & Junk Bond Yield & $\begin{array}{c}-0.037 \\
(0.033)\end{array}$ & $\begin{array}{l}-0.019 \\
(0.028)\end{array}$ & $\begin{array}{c}0.035 \\
(0.046)\end{array}$ & $\begin{array}{c}-0.046 \\
(0.030)\end{array}$ & $\begin{array}{l}-0.001 \\
(0.020)\end{array}$ \\
\hline & S\&P 500 & $\begin{array}{c}0.134 * \\
(0.069)\end{array}$ & $\begin{array}{c}0.150 * * \\
(0.060)\end{array}$ & $\begin{array}{c}0.196 * * \\
(0.089)\end{array}$ & $\begin{array}{c}0.141 * * \\
(0.064)\end{array}$ & $\begin{array}{c}0.148 * * * \\
(0.042)\end{array}$ \\
\hline & Exchange Rate & $\begin{array}{c}-0.411 * * * \\
(0.150)\end{array}$ & $\begin{array}{c}-0.578 * * * \\
(0.129)\end{array}$ & $\begin{array}{c}-0.147 \\
(0.210)\end{array}$ & $\begin{array}{c}-0.555^{* * *} * \\
(0.133)\end{array}$ & $\begin{array}{c}-0.337 * * * \\
(0.098)\end{array}$ \\
\hline & Gasoline $(-1)$ & $\begin{array}{c}0.063 \\
(0.045)\end{array}$ & $\begin{array}{l}-0.042 \\
(0.037)\end{array}$ & $\begin{array}{c}-0.091 \\
(0.056)\end{array}$ & $\begin{array}{c}-0.022 \\
(0.038)\end{array}$ & $\begin{array}{c}0.034 \\
(0.025)\end{array}$ \\
\hline & Heating Oil(-1) & $\begin{array}{c}-0.116^{* *} \\
(0.055)\end{array}$ & $\begin{array}{l}-0.027 \\
(0.051)\end{array}$ & $\begin{array}{c}-0.019 \\
(0.070)\end{array}$ & $\begin{array}{c}-0.064 \\
(0.052)\end{array}$ & $\begin{array}{l}-0.014 \\
(0.031)\end{array}$ \\
\hline & Natural Gas(-1) & $\begin{array}{c}0.042 * * \\
(0.020)\end{array}$ & $\begin{array}{c}0.064 * * * \\
(0.018)\end{array}$ & $\begin{array}{c}0.193 * * * \\
(0.034)\end{array}$ & $\begin{array}{c}0.060 * * * \\
(0.018)\end{array}$ & $\begin{array}{c}-0.036^{* * *} \\
(0.012)\end{array}$ \\
\hline & Crude Oil(-1) & $\begin{array}{c}0.183 * * * \\
(0.057)\end{array}$ & $\begin{array}{c}0.206^{* * * *} \\
(0.050)\end{array}$ & $\begin{array}{c}0.114 * \\
(0.067)\end{array}$ & $\begin{array}{c}0.192 * * * \\
(0.054)\end{array}$ & $\begin{array}{l}-0.021 \\
(0.031)\end{array}$ \\
\hline & Soybean Oil(-1) & $\begin{array}{l}-0.009 \\
(0.045)\end{array}$ & $\begin{array}{l}-0.048 \\
(0.038)\end{array}$ & $\begin{array}{l}-0.063 \\
(0.061)\end{array}$ & $\begin{array}{c}-0.053 \\
(0.039)\end{array}$ & $\begin{array}{c}0.186 * * * \\
(0.032)\end{array}$ \\
\hline & Working's T Gasoline & $\begin{array}{c}-0.097 * * \\
(0.045)\end{array}$ & $\begin{array}{c}0.015 \\
(0.038)\end{array}$ & $\begin{array}{c}0.090 \\
(0.065)\end{array}$ & $\begin{array}{c}-0.055 \\
(0.038)\end{array}$ & $\begin{array}{c}0.006 \\
(0.029)\end{array}$ \\
\hline & Working's T Heating Oil & $\begin{array}{c}0.000 \\
(0.031)\end{array}$ & $\begin{array}{c}-0.062 * * \\
(0.027)\end{array}$ & $\begin{array}{c}-0.058 \\
(0.045)\end{array}$ & $\begin{array}{c}-0.031 \\
(0.027)\end{array}$ & $\begin{array}{l}-0.029 \\
(0.020)\end{array}$ \\
\hline & Working's T Natural Gas & $\begin{array}{c}0.007 \\
(0.021)\end{array}$ & $\begin{array}{c}0.002 \\
(0.018)\end{array}$ & $\begin{array}{l}-0.051 * \\
(0.027)\end{array}$ & $\begin{array}{c}-0.001 \\
(0.019)\end{array}$ & $\begin{array}{c}-0.002 \\
(0.014)\end{array}$ \\
\hline & Working's T Crude Oil & $\begin{array}{c}-0.008 \\
(0.051)\end{array}$ & $\begin{array}{c}0.023 \\
(0.044)\end{array}$ & $\begin{array}{c}0.031 \\
(0.063)\end{array}$ & $\begin{array}{c}0.029 \\
(0.045)\end{array}$ & $\begin{array}{c}0.022 \\
(0.030)\end{array}$ \\
\hline & Working's T Soybean Oil & $\begin{array}{l}-0.016 \\
(0.019)\end{array}$ & $\begin{array}{l}-0.014 \\
(0.016)\end{array}$ & $\begin{array}{c}-0.062 * * \\
(0.028)\end{array}$ & $\begin{array}{l}-0.010 \\
(0.017)\end{array}$ & $\begin{array}{c}-0.042 * * * \\
(0.011)\end{array}$ \\
\hline & Constant & $\begin{array}{c}0.128 * * \\
(0.056)\end{array}$ & $\begin{array}{c}0.045 \\
(0.048)\end{array}$ & $\begin{array}{c}0.064 \\
(0.076)\end{array}$ & $\begin{array}{c}0.078 \\
(0.050)\end{array}$ & $\begin{array}{l}0.054^{*} \\
(0.033)\end{array}$ \\
\hline \multirow{12}{*}{ 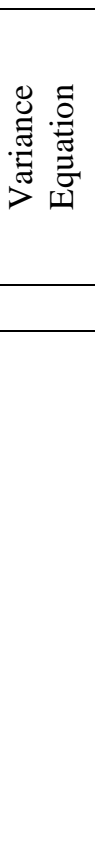 } & $\mathrm{ARCH}(1)$ & $\begin{array}{c}0.091 * * * \\
(0.021)\end{array}$ & $\begin{array}{c}0.093 * * * \\
(0.017)\end{array}$ & $\begin{array}{c}0.145 * * * \\
(0.032)\end{array}$ & $\begin{array}{c}0.105^{* * *} * \\
(0.016)\end{array}$ & $\begin{array}{c}0.154 * * * \\
(0.047)\end{array}$ \\
\hline & GARCH(1) & $\begin{array}{c}0.828 * * * \\
(0.042)\end{array}$ & $\begin{array}{l}0.850 * * * \\
(0.028)\end{array}$ & $\begin{array}{l}0.760 * * * \\
(0.044)\end{array}$ & $\begin{array}{l}0.844 * * * \\
(0.020)\end{array}$ & $\begin{array}{l}0.696 * * * \\
(0.108)\end{array}$ \\
\hline & Constant & $\begin{array}{l}0.000 * * * \\
(0.000)\end{array}$ & $\begin{array}{l}0.000 * * * \\
(0.000)\end{array}$ & $\begin{array}{l}0.000 * * * \\
(0.000)\end{array}$ & $\begin{array}{l}0.000 * * * \\
(0.000)\end{array}$ & $\begin{array}{c}0.000 * * \\
(0.000)\end{array}$ \\
\hline & F-stat on Working's T & $13.770 * *$ & 8.790 & 8.630 & $10.310 *$ & $18.910 * * *$ \\
\hline & Log Likelihood & & & 11136 & & \\
\hline & AIC & & & -22067 & & \\
\hline & $\mathrm{BIC}$ & & & -21554 & & \\
\hline & Degree of Freedom & & & $\begin{array}{l}9.724 * * * \\
(1.065)\end{array}$ & & \\
\hline & Lambda 1 & & & $\begin{array}{l}0.050 * * * \\
(0.009)\end{array}$ & & \\
\hline & Lambda 2 & & & $\begin{array}{l}0.816 * * * \\
(0.038)\end{array}$ & & \\
\hline & $\begin{array}{l}\text { Test for Lambda } 1=\text { Lambda } \\
2=0(\text { Chi } 2(2))\end{array}$ & & & $1400.520 * * *$ & & \\
\hline & N. of Obs. & 1076 & 1076 & 1076 & 1076 & 1076 \\
\hline
\end{tabular}

Notes: The error distribution is a multivariate Student's T. Standard errors in parentheses. * significant at $10 \%$ level, ** significant at $5 \%$ level, *** significant at $1 \%$ level. 
Table 7.b: Descriptive statistics of dynamic conditional correlations on "fuels" group

\begin{tabular}{lcccccrr}
\hline \hline Returns & N. of Obs. & Mean & Std. Dev. & Min & Max & Skew. & Kurt. \\
\hline Gasoline, Heating Oil & 1076 & 0.706 & 0.064 & 0.100 & 0.852 & -2.256 & 16.889 \\
Gasoline, Natural Gas & 1076 & 0.219 & 0.084 & -0.199 & 0.568 & -0.341 & 4.721 \\
Gasoline, Crude Oil & 1076 & 0.723 & 0.059 & 0.102 & 0.855 & -3.086 & 25.343 \\
Gasoline, Soybean Oil & 1076 & 0.130 & 0.089 & -0.112 & 0.490 & 0.533 & 4.279 \\
Heating Oil, Natural Gas & 1076 & 0.330 & 0.075 & 0.047 & 0.574 & -0.267 & 3.317 \\
Heating Oil, Crude Oil & 1076 & 0.773 & 0.059 & 0.108 & 0.875 & -4.115 & 35.206 \\
Heating Oil, Soybean Oil & 1076 & 0.164 & 0.097 & -0.136 & 0.466 & 0.296 & 3.523 \\
Natural Gas, Crude Oil & 1076 & 0.219 & 0.082 & -0.206 & 0.430 & -0.832 & 5.120 \\
Natural Gas, Soybean Oil & 1076 & 0.129 & 0.076 & -0.090 & 0.419 & 0.287 & 3.203 \\
Crude Oil, Soybean Oil & 1076 & 0.126 & 0.094 & -0.146 & 0.519 & 0.478 & 4.175 \\
\hline \hline
\end{tabular}


Table 8.a: CCC model on "agriculture" group

\begin{tabular}{|c|c|c|c|c|c|c|}
\hline & & Corn & Oats & Soybeans & Wheat & Soybean Oil \\
\hline \multirow{15}{*}{ 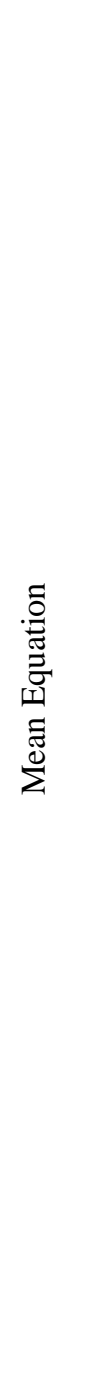 } & Tbill & $\begin{array}{c}0.016 \\
(0.012)\end{array}$ & $\begin{array}{l}-0.003 \\
(0.013)\end{array}$ & $\begin{array}{l}0.018 * \\
(0.011)\end{array}$ & $\begin{array}{c}0.014 \\
(0.011)\end{array}$ & $\begin{array}{l}0.019 * \\
(0.011)\end{array}$ \\
\hline & Junk Bond Yield & $\begin{array}{l}-0.007 \\
(0.018)\end{array}$ & $\begin{array}{l}-0.020 \\
(0.026)\end{array}$ & $\begin{array}{c}-0.014 \\
(0.015)\end{array}$ & $\begin{array}{l}-0.009 \\
(0.017)\end{array}$ & $\begin{array}{l}-0.019 \\
(0.019)\end{array}$ \\
\hline & S\&P 500 & $\begin{array}{c}0.075 * * \\
(0.036)\end{array}$ & $\begin{array}{l}0.085^{*} \\
(0.049)\end{array}$ & $\begin{array}{c}0.098 * * * \\
(0.031)\end{array}$ & $\begin{array}{c}0.047 \\
(0.034)\end{array}$ & $\begin{array}{c}0.096 * * * \\
(0.036)\end{array}$ \\
\hline & Exchange Rate & $\begin{array}{l}-0.133 \\
(0.082)\end{array}$ & $\begin{array}{l}-0.167 \\
(0.119)\end{array}$ & $\begin{array}{c}-0.133 * \\
(0.070)\end{array}$ & $\begin{array}{c}-0.143 * \\
(0.081)\end{array}$ & $\begin{array}{c}-0.232 * * * \\
(0.085)\end{array}$ \\
\hline & Corn(-1) & $\begin{array}{c}0.174 * * * \\
(0.037)\end{array}$ & $\begin{array}{l}-0.043 \\
(0.048)\end{array}$ & $\begin{array}{c}0.020 \\
(0.030)\end{array}$ & $\begin{array}{l}-0.025 \\
(0.034)\end{array}$ & $\begin{array}{c}0.032 \\
(0.032)\end{array}$ \\
\hline & Oats(-1) & $\begin{array}{c}0.022 \\
(0.021)\end{array}$ & $\begin{array}{c}0.199 * * * \\
(0.032)\end{array}$ & $\begin{array}{c}0.020 \\
(0.017)\end{array}$ & $\begin{array}{c}0.030 \\
(0.019)\end{array}$ & $\begin{array}{c}0.004 \\
(0.020)\end{array}$ \\
\hline & Soybeans(-1) & $\begin{array}{c}-0.051 \\
(0.042)\end{array}$ & $\begin{array}{l}-0.012 \\
(0.055)\end{array}$ & $\begin{array}{c}0.145^{* * * *} \\
(0.039)\end{array}$ & $\begin{array}{l}-0.022 \\
(0.038)\end{array}$ & $\begin{array}{c}-0.035 \\
(0.039)\end{array}$ \\
\hline & Wheat(-1) & $\begin{array}{c}-0.015 \\
(0.030)\end{array}$ & $\begin{array}{c}0.028 \\
(0.040)\end{array}$ & $\begin{array}{l}-0.027 \\
(0.024)\end{array}$ & $\begin{array}{c}0.169 * * * \\
(0.031)\end{array}$ & $\begin{array}{c}0.003 \\
(0.027)\end{array}$ \\
\hline & Soybean Oil(-1) & $\begin{array}{c}0.011 \\
(0.035)\end{array}$ & $\begin{array}{c}-0.018 \\
(0.050)\end{array}$ & $\begin{array}{c}0.016 \\
(0.030)\end{array}$ & $\begin{array}{c}0.029 \\
(0.033)\end{array}$ & $\begin{array}{c}0.191 * * * \\
(0.035)\end{array}$ \\
\hline & Working's T Corn & $\begin{array}{l}-0.018 \\
(0.016)\end{array}$ & $\begin{array}{c}-0.051 * * \\
(0.022)\end{array}$ & $\begin{array}{c}0.001 \\
(0.013)\end{array}$ & $\begin{array}{c}-0.039 * * * \\
(0.015)\end{array}$ & $\begin{array}{c}0.009 \\
(0.015)\end{array}$ \\
\hline & Working's T Oats & $\begin{array}{c}0.002 \\
(0.008)\end{array}$ & $\begin{array}{c}0.013 \\
(0.011)\end{array}$ & $\begin{array}{c}0.003 \\
(0.006)\end{array}$ & $\begin{array}{l}-0.003 \\
(0.007)\end{array}$ & $\begin{array}{l}-0.002 \\
(0.007)\end{array}$ \\
\hline & Working's T Soybeans & $\begin{array}{c}0.005 \\
(0.012)\end{array}$ & $\begin{array}{l}-0.002 \\
(0.017)\end{array}$ & $\begin{array}{l}-0.008 \\
(0.010)\end{array}$ & $\begin{array}{c}0.006 \\
(0.011)\end{array}$ & $\begin{array}{l}-0.010 \\
(0.011)\end{array}$ \\
\hline & Working's T Wheat & $\begin{array}{l}-0.010 \\
(0.014)\end{array}$ & $\begin{array}{c}0.002 \\
(0.019)\end{array}$ & $\begin{array}{c}0.002 \\
(0.012)\end{array}$ & $\begin{array}{c}-0.014 \\
(0.013)\end{array}$ & $\begin{array}{c}0.000 \\
(0.013)\end{array}$ \\
\hline & Working's T Soybean Oil & $\begin{array}{l}-0.013 \\
(0.013)\end{array}$ & $\begin{array}{c}0.001 \\
(0.017)\end{array}$ & $\begin{array}{c}-0.028 * * \\
(0.011)\end{array}$ & $\begin{array}{c}0.010 \\
(0.013)\end{array}$ & $\begin{array}{c}-0.029 * * \\
(0.012)\end{array}$ \\
\hline & Constant & $\begin{array}{c}0.042 \\
(0.027) \\
\end{array}$ & $\begin{array}{c}0.048 \\
(0.035) \\
\end{array}$ & $\begin{array}{c}0.037 \\
(0.022)\end{array}$ & $\begin{array}{c}0.049 * * \\
(0.025)\end{array}$ & $\begin{array}{c}0.037 \\
(0.025) \\
\end{array}$ \\
\hline \multirow{9}{*}{ 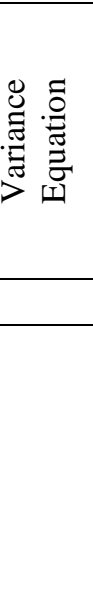 } & $\mathrm{ARCH}(1)$ & $\begin{array}{c}0.096 * * * \\
(0.018)\end{array}$ & $\begin{array}{c}0.091 * * * \\
(0.024)\end{array}$ & $\begin{array}{c}0.121 * * * \\
(0.018)\end{array}$ & $\begin{array}{c}0.078 * * * \\
(0.019)\end{array}$ & $\begin{array}{c}0.044 * * * \\
(0.011)\end{array}$ \\
\hline & GARCH(1) & $\begin{array}{c}0.841 * * * \\
(0.030)\end{array}$ & $\begin{array}{c}0.776 * * * \\
(0.065)\end{array}$ & $\begin{array}{c}0.843 * * * \\
(0.020)\end{array}$ & $\begin{array}{c}0.894 * * * \\
(0.027)\end{array}$ & $\begin{array}{c}0.915^{* * * *} \\
(0.023)\end{array}$ \\
\hline & Constant & $\begin{array}{c}0.000 * * * \\
(0.000)\end{array}$ & $\begin{array}{c}0.000 * * * \\
(0.000)\end{array}$ & $\begin{array}{c}0.000 * * * \\
(0.000)\end{array}$ & $\begin{array}{c}0.000 * * \\
(0.000)\end{array}$ & $\begin{array}{c}0.000 * * * \\
(0.000)\end{array}$ \\
\hline & F-stat on Working's T & 3.510 & 7.700 & $12.150 * *$ & $9.900 *$ & $10.770 *$ \\
\hline & Log Likelihood & & & 15244 & & \\
\hline & $\mathrm{AIC}$ & & & -30285 & & \\
\hline & $\mathrm{BIC}$ & & & -29763 & & \\
\hline & Degree of Freedom & & & $\begin{array}{c}7.490 * * * \\
(0.636)\end{array}$ & & \\
\hline & N. of Obs. & 1297 & 1297 & 1297 & 1297 & 1297 \\
\hline
\end{tabular}

Notes: The error distribution is a multivariate Student's T. Standard errors in parentheses. * significant at 10\% level, ** significant at 5\% level, $* * *$ significant at $1 \%$ level. 
Table 8.b: Conditional correlations of CCC model on "agriculture" group

\begin{tabular}{|c|c|c|c|c|c|}
\hline & Corn & Oats & Soybeans & Wheat & Soybean Oil \\
\hline Corn & 1 & & & & \\
\hline Oats & $\begin{array}{c}0.502 * * * \\
(0.022)\end{array}$ & 1 & & & \\
\hline Soybeans & $\begin{array}{c}0.611 * * * \\
(0.019)\end{array}$ & $\begin{array}{c}0.378 * * * \\
(0.026)\end{array}$ & 1 & & \\
\hline Wheat & $\begin{array}{c}0.523 * * * \\
(0.022)\end{array}$ & $\begin{array}{c}0.375^{* * * *} \\
(0.026)\end{array}$ & $\begin{array}{c}0.343 * * * \\
(0.026)\end{array}$ & 1 & \\
\hline Soybean Oil & $\begin{array}{c}0.475 * * * \\
(0.023)\end{array}$ & $\begin{array}{c}0.329 * * * \\
(0.027)\end{array}$ & $\begin{array}{c}0.678 * * * \\
(0.016)\end{array}$ & $\begin{array}{c}0.279 * * * \\
(0.027)\end{array}$ & 1 \\
\hline
\end{tabular}

Notes: * significant at $10 \%$ level, $* *$ significant at $5 \%$ level, $* * *$ significant at $1 \%$ level. 
Table 9.a: DCC model on "agriculture" group

\begin{tabular}{|c|c|c|c|c|c|c|}
\hline & & Corn & Oats & Soybeans & Wheat & Soybean Oil \\
\hline \multirow{15}{*}{ 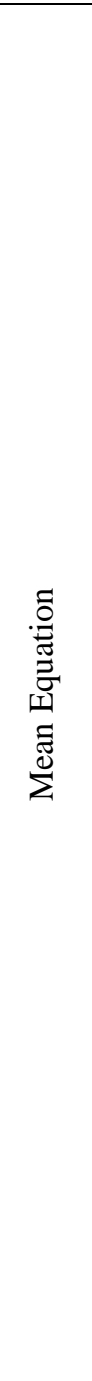 } & Tbill & $\begin{array}{c}0.014 \\
(0.012)\end{array}$ & $\begin{array}{c}-0.003 \\
(0.014)\end{array}$ & $\begin{array}{c}0.017 \\
(0.011)\end{array}$ & $\begin{array}{c}0.013 \\
(0.011)\end{array}$ & $\begin{array}{c}0.016 \\
(0.011)\end{array}$ \\
\hline & Junk Bond Yield & $\begin{array}{c}-0.010 \\
(0.018)\end{array}$ & $\begin{array}{c}-0.024 \\
(0.025)\end{array}$ & $\begin{array}{l}-0.017 \\
(0.015)\end{array}$ & $\begin{array}{l}-0.011 \\
(0.017)\end{array}$ & $\begin{array}{c}-0.024 \\
(0.019)\end{array}$ \\
\hline & S\&P 500 & $\begin{array}{l}0.068 * \\
(0.036)\end{array}$ & $\begin{array}{c}0.076 \\
(0.049)\end{array}$ & $\begin{array}{c}0.088 * * * \\
(0.031)\end{array}$ & $\begin{array}{c}0.038 \\
(0.034)\end{array}$ & $\begin{array}{c}0.091 * * \\
(0.036)\end{array}$ \\
\hline & Exchange Rate & $\begin{array}{l}-0.129 \\
(0.083)\end{array}$ & $\begin{array}{c}-0.175 \\
(0.120)\end{array}$ & $\begin{array}{c}-0.156^{* *} \\
(0.071)\end{array}$ & $\begin{array}{l}-0.144 * \\
(0.081)\end{array}$ & $\begin{array}{c}-0.258 * * * \\
(0.086)\end{array}$ \\
\hline & Corn $(-1)$ & $\begin{array}{c}0.170 * * * \\
(0.037)\end{array}$ & $\begin{array}{c}-0.032 \\
(0.047)\end{array}$ & $\begin{array}{c}0.026 \\
(0.029)\end{array}$ & $\begin{array}{c}-0.031 \\
(0.033)\end{array}$ & $\begin{array}{c}0.037 \\
(0.032)\end{array}$ \\
\hline & Oats(-1) & $\begin{array}{c}0.022 \\
(0.021)\end{array}$ & $\begin{array}{c}0.189 * * * \\
(0.032)\end{array}$ & $\begin{array}{c}0.016 \\
(0.017)\end{array}$ & $\begin{array}{c}0.025 \\
(0.019)\end{array}$ & $\begin{array}{c}-0.003 \\
(0.020)\end{array}$ \\
\hline & Soybeans(-1) & $\begin{array}{c}-0.051 \\
(0.041)\end{array}$ & $\begin{array}{c}-0.010 \\
(0.055)\end{array}$ & $\begin{array}{c}0.135 * * * \\
(0.038)\end{array}$ & $\begin{array}{c}-0.015 \\
(0.038)\end{array}$ & $\begin{array}{c}-0.038 \\
(0.039)\end{array}$ \\
\hline & Wheat(-1) & $\begin{array}{c}-0.014 \\
(0.029)\end{array}$ & $\begin{array}{c}0.036 \\
(0.040)\end{array}$ & $\begin{array}{l}-0.024 \\
(0.024)\end{array}$ & $\begin{array}{c}0.175 * * * \\
(0.031)\end{array}$ & $\begin{array}{c}0.008 \\
(0.027)\end{array}$ \\
\hline & Soybean Oil(-1) & $\begin{array}{c}0.024 \\
(0.035)\end{array}$ & $\begin{array}{c}-0.019 \\
(0.050)\end{array}$ & $\begin{array}{c}0.020 \\
(0.030)\end{array}$ & $\begin{array}{c}0.032 \\
(0.033)\end{array}$ & $\begin{array}{c}0.193 * * * \\
(0.035)\end{array}$ \\
\hline & Working's T Corn & $\begin{array}{l}-0.020 \\
(0.016)\end{array}$ & $\begin{array}{c}-0.047 * * \\
(0.022)\end{array}$ & $\begin{array}{c}-0.000 \\
(0.013)\end{array}$ & $\begin{array}{c}-0.039 * * * \\
(0.015)\end{array}$ & $\begin{array}{c}0.007 \\
(0.015)\end{array}$ \\
\hline & Working's T Oats & $\begin{array}{c}0.002 \\
(0.008)\end{array}$ & $\begin{array}{c}0.011 \\
(0.010)\end{array}$ & $\begin{array}{c}0.003 \\
(0.006)\end{array}$ & $\begin{array}{c}-0.004 \\
(0.007)\end{array}$ & $\begin{array}{c}-0.001 \\
(0.007)\end{array}$ \\
\hline & Working's T Soybeans & $\begin{array}{c}0.004 \\
(0.012)\end{array}$ & $\begin{array}{c}-0.002 \\
(0.017)\end{array}$ & $\begin{array}{c}-0.006 \\
(0.010)\end{array}$ & $\begin{array}{c}0.004 \\
(0.011)\end{array}$ & $\begin{array}{c}-0.008 \\
(0.011)\end{array}$ \\
\hline & Working's T Wheat & $\begin{array}{c}-0.007 \\
(0.013)\end{array}$ & $\begin{array}{c}0.006 \\
(0.018)\end{array}$ & $\begin{array}{c}0.002 \\
(0.012)\end{array}$ & $\begin{array}{l}-0.010 \\
(0.013)\end{array}$ & $\begin{array}{c}0.000 \\
(0.013)\end{array}$ \\
\hline & Working's T Soybean Oil & $\begin{array}{c}-0.012 \\
(0.013)\end{array}$ & $\begin{array}{c}0.003 \\
(0.017)\end{array}$ & $\begin{array}{c}-0.028 * * * \\
(0.011)\end{array}$ & $\begin{array}{c}0.012 \\
(0.013)\end{array}$ & $\begin{array}{c}-0.030^{* * *} \\
(0.012)\end{array}$ \\
\hline & Constant & $\begin{array}{c}0.040 \\
(0.026)\end{array}$ & $\begin{array}{c}0.037 \\
(0.035)\end{array}$ & $\begin{array}{c}0.036 \\
(0.022)\end{array}$ & $\begin{array}{l}0.045^{*} \\
(0.025)\end{array}$ & $\begin{array}{c}0.039 \\
(0.024)\end{array}$ \\
\hline \multirow{12}{*}{ 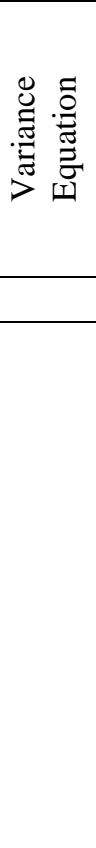 } & $\mathrm{ARCH}(1)$ & $\begin{array}{c}0.109 * * * \\
(0.020)\end{array}$ & $\begin{array}{c}0.096 * * * \\
(0.024)\end{array}$ & $\begin{array}{c}0.124 * * * \\
(0.017)\end{array}$ & $\begin{array}{c}0.088 * * * \\
(0.021)\end{array}$ & $\begin{array}{c}0.054 * * * \\
(0.012)\end{array}$ \\
\hline & GARCH(1) & $\begin{array}{c}0.831 * * * \\
(0.029)\end{array}$ & $\begin{array}{l}0.781 * * * \\
(0.060)\end{array}$ & $\begin{array}{l}0.846^{* * * *} \\
(0.019)\end{array}$ & $\begin{array}{l}0.882 * * * \\
(0.029)\end{array}$ & $\begin{array}{c}0.909 * * * \\
(0.022)\end{array}$ \\
\hline & Constant & $\begin{array}{l}0.000 * * * \\
(0.000)\end{array}$ & $\begin{array}{l}0.000 * * * \\
(0.000)\end{array}$ & $\begin{array}{l}0.000 * * * \\
(0.000)\end{array}$ & $\begin{array}{c}0.000 * * \\
(0.000)\end{array}$ & $\begin{array}{l}0.000 * * * \\
(0.000)\end{array}$ \\
\hline & F-stat on Working's T & 3.320 & 6.170 & $11.360 * *$ & 9.100 & $11.340 * *$ \\
\hline & Log Likelihood & & & 15274 & & \\
\hline & AIC & & & -30342 & & \\
\hline & $\mathrm{BIC}$ & & & -29810 & & \\
\hline & Degree of Freedom & & & $\begin{array}{l}7.715 * * * \\
(0.669)\end{array}$ & & \\
\hline & Lambda 1 & & & $\begin{array}{l}0.022 * * * \\
(0.006)\end{array}$ & & \\
\hline & Lambda 2 & & & $\begin{array}{l}0.928 * * * \\
(0.025)\end{array}$ & & \\
\hline & $\begin{array}{l}\text { Test for Lambda } 1=\text { Lambda } 2 \\
=0(\text { Chi2 } 2(2))\end{array}$ & & & $5267.510 * * *$ & & \\
\hline & N. of Obs. & 1297 & 1297 & 1297 & 1297 & 1297 \\
\hline
\end{tabular}

Notes: The error distribution is a multivariate Student's T. Standard errors in parentheses. ${ }^{*}$ significant at $10 \%$ level, $* *$ significant at $5 \%$ level, *** significant at $1 \%$ level. 
Table 9.b: Descriptive statistics of dynamic conditional correlations on "agriculture" group

\begin{tabular}{lcccccrr}
\hline \hline Returns & N. of Obs. & Mean & Std. Dev. & Min & Max & Skew. & Kurt. \\
\hline Corn, Oats & 1297 & 0.481 & 0.077 & 0.025 & 0.647 & -1.465 & 6.377 \\
Corn, Soybeans & 1297 & 0.607 & 0.069 & 0.031 & 0.733 & -2.925 & 20.214 \\
Corn, Wheat & 1297 & 0.510 & 0.075 & 0.026 & 0.677 & -1.672 & 8.814 \\
Corn, Soybean Oil & 1297 & 0.485 & 0.068 & 0.025 & 0.636 & -1.305 & 8.234 \\
Oats, Soybeans & 1297 & 0.377 & 0.070 & 0.019 & 0.583 & -0.527 & 4.830 \\
Oats, Wheat & 1297 & 0.355 & 0.070 & 0.018 & 0.599 & -0.405 & 3.815 \\
Oats, Soybean Oil & 1297 & 0.342 & 0.067 & 0.018 & 0.564 & -0.368 & 4.573 \\
Soybeans, Wheat & 1297 & 0.341 & 0.076 & 0.018 & 0.518 & -0.833 & 4.050 \\
Soybeans, Soybean Oil & 1297 & 0.687 & 0.069 & 0.035 & 0.811 & -3.906 & 29.986 \\
Wheat, Soybean Oil & 1297 & 0.284 & 0.069 & 0.015 & 0.457 & -0.584 & 3.730 \\
\hline \hline
\end{tabular}


Table 10.a: CCC model on "agriculture + factor of energy variables" group

\begin{tabular}{|c|c|c|c|c|c|c|c|}
\hline & & Corn & Oats & Soybeans & Wheat & Soybean Oil & Energy factor \\
\hline & Tbill & $\begin{array}{c}0.016 \\
(0.012)\end{array}$ & $\begin{array}{l}-0.004 \\
(0.014)\end{array}$ & $\begin{array}{c}0.017 \\
(0.011)\end{array}$ & $\begin{array}{c}0.014 \\
(0.011)\end{array}$ & $\begin{array}{c}0.015 \\
(0.010)\end{array}$ & $\begin{array}{c}0.894 * * * \\
(0.324)\end{array}$ \\
\hline & Junk Bond Yield & $\begin{array}{c}0.007 \\
(0.020)\end{array}$ & $\begin{array}{l}-0.016 \\
(0.029)\end{array}$ & $\begin{array}{l}-0.010 \\
(0.017)\end{array}$ & $\begin{array}{l}-0.004 \\
(0.021)\end{array}$ & $\begin{array}{l}-0.015 \\
(0.020)\end{array}$ & $\begin{array}{l}-0.729 \\
(0.669)\end{array}$ \\
\hline & S\&P 500 & $\begin{array}{c}0.123 * * * \\
(0.044)\end{array}$ & $\begin{array}{c}0.090 \\
(0.058)\end{array}$ & $\begin{array}{c}0.139 * * * \\
(0.038)\end{array}$ & $\begin{array}{c}0.042 \\
(0.044)\end{array}$ & $\begin{array}{c}0.151 * * * \\
(0.041)\end{array}$ & $\begin{array}{c}4.358 * * * \\
(1.447)\end{array}$ \\
\hline & Exchange Rate & $\begin{array}{c}-0.218 * * \\
(0.096)\end{array}$ & $\begin{array}{l}-0.230 * \\
(0.136)\end{array}$ & $\begin{array}{c}-0.185 * * \\
(0.082)\end{array}$ & $\begin{array}{c}-0.295^{* * *} \\
(0.103)\end{array}$ & $\begin{array}{c}-0.285^{* * * *} \\
(0.095)\end{array}$ & $\begin{array}{c}-14.550 * * * \\
(3.021)\end{array}$ \\
\hline & Corn(-1) & $\begin{array}{c}0.173 * * * \\
(0.042)\end{array}$ & $\begin{array}{l}-0.053 \\
(0.053)\end{array}$ & $\begin{array}{c}0.033 \\
(0.035)\end{array}$ & $\begin{array}{c}0.031 \\
(0.042)\end{array}$ & $\begin{array}{c}0.032 \\
(0.035)\end{array}$ & $\begin{array}{c}0.450 \\
(1.122)\end{array}$ \\
\hline & Oats(-1) & $\begin{array}{l}-0.002 \\
(0.024)\end{array}$ & $\begin{array}{c}0.183 * * * \\
(0.036)\end{array}$ & $\begin{array}{c}0.006 \\
(0.020)\end{array}$ & $\begin{array}{c}0.004 \\
(0.024)\end{array}$ & $\begin{array}{l}-0.002 \\
(0.022)\end{array}$ & $\begin{array}{l}-0.185 \\
(0.730)\end{array}$ \\
\hline & Soybeans(-1) & $\begin{array}{l}-0.038 \\
(0.046)\end{array}$ & $\begin{array}{c}0.004 \\
(0.060)\end{array}$ & $\begin{array}{c}0.137 * * * \\
(0.044)\end{array}$ & $\begin{array}{l}-0.037 \\
(0.046)\end{array}$ & $\begin{array}{l}-0.023 \\
(0.042)\end{array}$ & $\begin{array}{c}1.276 \\
(1.382)\end{array}$ \\
\hline & Wheat(-1) & $\begin{array}{l}-0.009 \\
(0.032)\end{array}$ & $\begin{array}{c}0.027 \\
(0.042)\end{array}$ & $\begin{array}{l}-0.019 \\
(0.027)\end{array}$ & $\begin{array}{c}0.165 * * * \\
(0.036)\end{array}$ & $\begin{array}{c}0.007 \\
(0.029)\end{array}$ & $\begin{array}{l}1.590 * \\
(0.908)\end{array}$ \\
\hline & Soybean Oil(-1) & $\begin{array}{l}-0.007 \\
(0.040)\end{array}$ & $\begin{array}{l}-0.011 \\
(0.056)\end{array}$ & $\begin{array}{c}0.022 \\
(0.035)\end{array}$ & $\begin{array}{c}0.003 \\
(0.042)\end{array}$ & $\begin{array}{c}0.177 * * * \\
(0.039)\end{array}$ & $\begin{array}{c}-3.183 * * \\
(1.307)\end{array}$ \\
\hline 导 & Energy factor(-1) & $\begin{array}{l}-0.001 \\
(0.001)\end{array}$ & $\begin{array}{c}0.000 \\
(0.001)\end{array}$ & $\begin{array}{c}0.000 \\
(0.001)\end{array}$ & $\begin{array}{l}-0.001 * \\
(0.001)\end{array}$ & $\begin{array}{c}0.000 \\
(0.001)\end{array}$ & $\begin{array}{c}0.181 * * * \\
(0.032)\end{array}$ \\
\hline 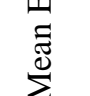 & Working's T Corn & $\begin{array}{l}-0.017 \\
(0.018)\end{array}$ & $\begin{array}{c}-0.056^{* *} \\
(0.025)\end{array}$ & $\begin{array}{c}0.004 \\
(0.015)\end{array}$ & $\begin{array}{c}-0.036 * * \\
(0.018)\end{array}$ & $\begin{array}{c}0.009 \\
(0.017)\end{array}$ & $\begin{array}{c}-1.364 * * \\
(0.542)\end{array}$ \\
\hline & Working's T Oats & $\begin{array}{c}0.002 \\
(0.012)\end{array}$ & $\begin{array}{l}0.030 * \\
(0.016)\end{array}$ & $\begin{array}{c}-0.003 \\
(0.011)\end{array}$ & $\begin{array}{c}-0.001 \\
(0.013)\end{array}$ & $\begin{array}{l}-0.005 \\
(0.012)\end{array}$ & $\begin{array}{c}0.580 \\
(0.375)\end{array}$ \\
\hline & Working's T Soybeans & $\begin{array}{l}-0.005 \\
(0.015)\end{array}$ & $\begin{array}{c}0.002 \\
(0.022)\end{array}$ & $\begin{array}{c}-0.022 * \\
(0.013)\end{array}$ & $\begin{array}{c}0.010 \\
(0.016)\end{array}$ & $\begin{array}{l}-0.019 \\
(0.015)\end{array}$ & $\begin{array}{c}-0.273 \\
(0.483)\end{array}$ \\
\hline & Working's T Wheat & $\begin{array}{l}-0.025 \\
(0.017)\end{array}$ & $\begin{array}{c}-0.014 \\
(0.023)\end{array}$ & $\begin{array}{c}0.012 \\
(0.015)\end{array}$ & $\begin{array}{l}-0.026 \\
(0.018)\end{array}$ & $\begin{array}{c}0.006 \\
(0.016)\end{array}$ & $\begin{array}{c}0.432 \\
(0.497)\end{array}$ \\
\hline & Working's T Soybean Oil & $\begin{array}{c}-0.010 \\
(0.014)\end{array}$ & $\begin{array}{c}0.002 \\
(0.019)\end{array}$ & $\begin{array}{c}-0.030 * * \\
(0.012)\end{array}$ & $\begin{array}{c}0.006 \\
(0.014)\end{array}$ & $\begin{array}{c}-0.029 * * \\
(0.013)\end{array}$ & $\begin{array}{c}-0.077 \\
(0.430)\end{array}$ \\
\hline & Working's T Gasoline & $\begin{array}{c}0.003 \\
(0.027)\end{array}$ & $\begin{array}{c}0.019 \\
(0.040)\end{array}$ & $\begin{array}{c}0.022 \\
(0.024)\end{array}$ & $\begin{array}{c}0.044 \\
(0.030)\end{array}$ & $\begin{array}{l}-0.011 \\
(0.028)\end{array}$ & $\begin{array}{l}-0.791 \\
(0.905)\end{array}$ \\
\hline & Working's T Heating Oil & $\begin{array}{c}0.015 \\
(0.021)\end{array}$ & $\begin{array}{l}-0.005 \\
(0.029)\end{array}$ & $\begin{array}{c}0.003 \\
(0.019)\end{array}$ & $\begin{array}{l}-0.027 \\
(0.023)\end{array}$ & $\begin{array}{c}-0.003 \\
(0.021)\end{array}$ & $\begin{array}{l}-0.939 \\
(0.656)\end{array}$ \\
\hline & Working's T Natural Gas & $\begin{array}{c}0.021 \\
(0.016)\end{array}$ & $\begin{array}{c}0.011 \\
(0.021)\end{array}$ & $\begin{array}{c}-0.003 \\
(0.014)\end{array}$ & $\begin{array}{c}0.013 \\
(0.016)\end{array}$ & $\begin{array}{l}-0.010 \\
(0.015)\end{array}$ & $\begin{array}{l}-0.737 \\
(0.483)\end{array}$ \\
\hline & Working's T Crude Oil & $\begin{array}{l}-0.025 \\
(0.031)\end{array}$ & $\begin{array}{l}-0.024 \\
(0.045)\end{array}$ & $\begin{array}{l}-0.012 \\
(0.026)\end{array}$ & $\begin{array}{l}-0.027 \\
(0.033)\end{array}$ & $\begin{array}{c}0.018 \\
(0.030)\end{array}$ & $\begin{array}{c}0.952 \\
(1.059)\end{array}$ \\
\hline & Constant & $\begin{array}{c}0.051 \\
(0.046) \\
\end{array}$ & $\begin{array}{c}0.047 \\
(0.059) \\
\end{array}$ & $\begin{array}{c}0.038 \\
(0.039) \\
\end{array}$ & $\begin{array}{c}0.056 \\
(0.045) \\
\end{array}$ & $\begin{array}{c}0.052 \\
(0.041) \\
\end{array}$ & $\begin{array}{l}2.665^{*} \\
(1.436)\end{array}$ \\
\hline & $\mathrm{ARCH}(1)$ & $\begin{array}{c}0.095 * * * \\
(0.019)\end{array}$ & $\begin{array}{c}0.074 * * * \\
(0.025)\end{array}$ & $\begin{array}{c}0.118 * * * \\
(0.019)\end{array}$ & $\begin{array}{c}0.080 * * * \\
(0.023)\end{array}$ & $\begin{array}{c}0.046 * * * \\
(0.014)\end{array}$ & $\begin{array}{c}0.150 * * * \\
(0.033)\end{array}$ \\
\hline . & GARCH(1) & $\begin{array}{c}0.850 * * * \\
(0.031)\end{array}$ & $\begin{array}{c}0.831 * * * \\
(0.064)\end{array}$ & $\begin{array}{c}0.844 * * * \\
(0.022)\end{array}$ & $\begin{array}{c}0.873 * * * \\
(0.041)\end{array}$ & $\begin{array}{c}0.907 * * * \\
(0.030)\end{array}$ & $\begin{array}{c}0.794 * * * \\
(0.044)\end{array}$ \\
\hline & Constant & $\begin{array}{c}0.000 * * * \\
(0.000)\end{array}$ & $\begin{array}{c}0.000 * * \\
(0.000)\end{array}$ & $\begin{array}{c}0.000 * * * \\
(0.000)\end{array}$ & $\begin{array}{c}0.000 * * \\
(0.000)\end{array}$ & $\begin{array}{c}0.000 * * \\
(0.000)\end{array}$ & $\begin{array}{c}0.055 * * * \\
(0.020)\end{array}$ \\
\hline & F-stat on Working's T & 8.660 & 9.480 & $15.000 *$ & 11.400 & 13.130 & $20.400 * *$ \\
\hline & Log Likelihood & \multicolumn{6}{|c|}{11303} \\
\hline & AIC & \multicolumn{6}{|c|}{-22298} \\
\hline & BIC & \multicolumn{6}{|c|}{-21531} \\
\hline & Degree of Freedom & \multicolumn{6}{|c|}{$\begin{array}{c}9.395^{* * *} \\
(0.915)\end{array}$} \\
\hline & N. of Obs. & 1076 & 1076 & 1076 & 1076 & 1076 & 1076 \\
\hline
\end{tabular}

Notes: The error distribution is a multivariate Student's T. Standard errors in parentheses. * significant at $10 \%$ level, ** significant at 5\% level, *** significant at $1 \%$ level. 
Table 10.b: Conditional correlations of CCC model on "agriculture + factor of energy variables" group

\begin{tabular}{|c|c|c|c|c|c|c|}
\hline & Corn & Oats & Soybeans & Wheat & Soybean Oil & Energy factor \\
\hline Corn & 1 & & & & & \\
\hline Oats & $\begin{array}{c}0.523 * * * \\
(0.024)\end{array}$ & 1 & & & & \\
\hline Soybeans & $\begin{array}{c}0.612 * * * \\
(0.020)\end{array}$ & $\begin{array}{c}0.366^{* * * *} \\
(0.028)\end{array}$ & 1 & & & \\
\hline Wheat & $\begin{array}{c}0.530 * * * \\
(0.024)\end{array}$ & $\begin{array}{c}0.376^{* * * *} \\
(0.028)\end{array}$ & $\begin{array}{c}0.331 * * * \\
(0.029)\end{array}$ & 1 & & \\
\hline Soybean Oil & $\begin{array}{c}0.474 * * * \\
(0.025)\end{array}$ & $\begin{array}{c}0.326^{* * * *} \\
(0.029)\end{array}$ & $\begin{array}{c}0.687 * * * \\
(0.017)\end{array}$ & $\begin{array}{c}0.282 * * * \\
(0.030)\end{array}$ & 1 & \\
\hline Energy factor & $\begin{array}{l}0.055^{*} \\
(0.032)\end{array}$ & $\begin{array}{c}0.093 * * * \\
(0.032)\end{array}$ & $\begin{array}{c}0.105 * * * \\
(0.032)\end{array}$ & $\begin{array}{c}0.088 * * * \\
(0.032)\end{array}$ & $\begin{array}{c}0.134 * * * \\
(0.032)\end{array}$ & 1 \\
\hline
\end{tabular}

Notes: * significant at $10 \%$ level, $* *$ significant at $5 \%$ level, $* * *$ significant at $1 \%$ level. 
Table 11.a: DCC model on "agriculture + factor of energy variables" group

\begin{tabular}{|c|c|c|c|c|c|c|c|}
\hline & & Corn & Oats & Soybeans & Wheat & Soybean Oil & Energy factor \\
\hline \multirow{20}{*}{ 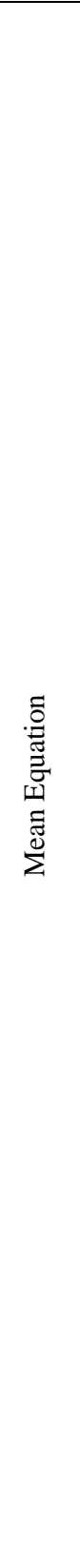 } & Tbill & $\begin{array}{c}0.013 \\
(0.012)\end{array}$ & $\begin{array}{l}-0.007 \\
(0.014)\end{array}$ & $\begin{array}{c}0.015 \\
(0.011)\end{array}$ & $\begin{array}{c}0.013 \\
(0.011)\end{array}$ & $\begin{array}{c}0.012 \\
(0.010)\end{array}$ & $\begin{array}{c}0.786^{* *} \\
(0.332)\end{array}$ \\
\hline & Junk Bond Yield & $\begin{array}{c}0.006 \\
(0.020)\end{array}$ & $\begin{array}{l}-0.017 \\
(0.029)\end{array}$ & $\begin{array}{l}-0.012 \\
(0.017)\end{array}$ & $\begin{array}{l}-0.005 \\
(0.020)\end{array}$ & $\begin{array}{l}-0.017 \\
(0.020)\end{array}$ & $\begin{array}{l}-0.775 \\
(0.666)\end{array}$ \\
\hline & S\&P 500 & $\begin{array}{c}0.105 * * \\
(0.044)\end{array}$ & $\begin{array}{c}0.071 \\
(0.058)\end{array}$ & $\begin{array}{c}0.125 * * * \\
(0.038)\end{array}$ & $\begin{array}{c}0.028 \\
(0.045)\end{array}$ & $\begin{array}{c}0.138 * * * \\
(0.041)\end{array}$ & $\begin{array}{c}3.676^{* *} \\
(1.428)\end{array}$ \\
\hline & Exchange Rate & $\begin{array}{c}-0.188^{*} \\
(0.096)\end{array}$ & $\begin{array}{l}-0.206 \\
(0.137)\end{array}$ & $\begin{array}{c}-0.193 * * \\
(0.082)\end{array}$ & $\begin{array}{c}-0.275 * * * \\
(0.104)\end{array}$ & $\begin{array}{c}-0.276 * * * \\
(0.095)\end{array}$ & $\begin{array}{c}-12.973 * * * \\
(3.038)\end{array}$ \\
\hline & Corn(-1) & $\begin{array}{c}0.165 * * * \\
(0.041)\end{array}$ & $\begin{array}{l}-0.046 \\
(0.052)\end{array}$ & $\begin{array}{c}0.039 \\
(0.034)\end{array}$ & $\begin{array}{c}0.023 \\
(0.041)\end{array}$ & $\begin{array}{c}0.036 \\
(0.034)\end{array}$ & $\begin{array}{c}0.480 \\
(1.093)\end{array}$ \\
\hline & Oats(-1) & $\begin{array}{c}-0.004 \\
(0.024)\end{array}$ & $\begin{array}{c}0.172 * * * \\
(0.036)\end{array}$ & $\begin{array}{c}0.000 \\
(0.020)\end{array}$ & $\begin{array}{l}-0.001 \\
(0.024)\end{array}$ & $\begin{array}{l}-0.009 \\
(0.022)\end{array}$ & $\begin{array}{l}-0.287 \\
(0.721)\end{array}$ \\
\hline & Soybeans(-1) & $\begin{array}{l}-0.039 \\
(0.046)\end{array}$ & $\begin{array}{c}0.000 \\
(0.059)\end{array}$ & $\begin{array}{c}0.125 * * * \\
(0.043)\end{array}$ & $\begin{array}{l}-0.035 \\
(0.046)\end{array}$ & $\begin{array}{l}-0.029 \\
(0.041)\end{array}$ & $\begin{array}{c}1.441 \\
(1.362)\end{array}$ \\
\hline & Wheat(-1) & $\begin{array}{l}-0.003 \\
(0.031)\end{array}$ & $\begin{array}{c}0.039 \\
(0.042)\end{array}$ & $\begin{array}{l}-0.015 \\
(0.026)\end{array}$ & $\begin{array}{c}0.171 * * * \\
(0.036)\end{array}$ & $\begin{array}{c}0.014 \\
(0.028)\end{array}$ & $\begin{array}{l}1.491 * \\
(0.886)\end{array}$ \\
\hline & Soybean Oil(-1) & $\begin{array}{c}0.004 \\
(0.040)\end{array}$ & $\begin{array}{l}-0.013 \\
(0.055)\end{array}$ & $\begin{array}{c}0.022 \\
(0.035)\end{array}$ & $\begin{array}{c}0.009 \\
(0.041)\end{array}$ & $\begin{array}{c}0.180 * * * \\
(0.039)\end{array}$ & $\begin{array}{c}-3.017 * * \\
(1.287)\end{array}$ \\
\hline & Energy factor(-1) & $\begin{array}{c}-0.001 \\
(0.001)\end{array}$ & $\begin{array}{l}-0.000 \\
(0.001)\end{array}$ & $\begin{array}{c}0.000 \\
(0.001)\end{array}$ & $\begin{array}{c}-0.001 * \\
(0.001)\end{array}$ & $\begin{array}{c}-0.000 \\
(0.001)\end{array}$ & $\begin{array}{c}0.174 * * * \\
(0.031)\end{array}$ \\
\hline & Working's T Corn & $\begin{array}{l}-0.018 \\
(0.018)\end{array}$ & $\begin{array}{c}-0.051 * * \\
(0.024)\end{array}$ & $\begin{array}{c}0.004 \\
(0.015)\end{array}$ & $\begin{array}{c}-0.035^{*} \\
(0.018)\end{array}$ & $\begin{array}{c}0.007 \\
(0.017)\end{array}$ & $\begin{array}{c}-1.278 * * \\
(0.540)\end{array}$ \\
\hline & Working's T Oats & $\begin{array}{l}-0.002 \\
(0.012)\end{array}$ & $\begin{array}{c}0.026 \\
(0.016)\end{array}$ & $\begin{array}{l}-0.006 \\
(0.011)\end{array}$ & $\begin{array}{l}-0.004 \\
(0.013)\end{array}$ & $\begin{array}{l}-0.006 \\
(0.012)\end{array}$ & $\begin{array}{c}0.494 \\
(0.372)\end{array}$ \\
\hline & Working's T Soybeans & $\begin{array}{c}-0.005 \\
(0.015)\end{array}$ & $\begin{array}{c}0.005 \\
(0.022)\end{array}$ & $\begin{array}{l}-0.020 \\
(0.013)\end{array}$ & $\begin{array}{c}0.008 \\
(0.016)\end{array}$ & $\begin{array}{l}-0.014 \\
(0.014)\end{array}$ & $\begin{array}{l}-0.171 \\
(0.480)\end{array}$ \\
\hline & Working's T Wheat & $\begin{array}{l}-0.022 \\
(0.017)\end{array}$ & $\begin{array}{l}-0.010 \\
(0.023)\end{array}$ & $\begin{array}{c}0.011 \\
(0.014)\end{array}$ & $\begin{array}{l}-0.019 \\
(0.017)\end{array}$ & $\begin{array}{c}0.006 \\
(0.015)\end{array}$ & $\begin{array}{c}0.381 \\
(0.490)\end{array}$ \\
\hline & Working's T Soybean Oil & $\begin{array}{l}-0.010 \\
(0.014)\end{array}$ & $\begin{array}{c}0.003 \\
(0.019)\end{array}$ & $\begin{array}{c}-0.029 * * \\
(0.012)\end{array}$ & $\begin{array}{c}0.007 \\
(0.014)\end{array}$ & $\begin{array}{c}-0.032 * * * \\
(0.012)\end{array}$ & $\begin{array}{l}-0.035 \\
(0.428)\end{array}$ \\
\hline & Working's T Gasoline & $\begin{array}{c}0.005 \\
(0.027)\end{array}$ & $\begin{array}{c}0.019 \\
(0.040)\end{array}$ & $\begin{array}{c}0.017 \\
(0.023)\end{array}$ & $\begin{array}{c}0.048 \\
(0.030)\end{array}$ & $\begin{array}{l}-0.013 \\
(0.028)\end{array}$ & $\begin{array}{l}-0.690 \\
(0.897)\end{array}$ \\
\hline & Working's T Heating Oil & $\begin{array}{c}0.016 \\
(0.021)\end{array}$ & $\begin{array}{l}-0.001 \\
(0.029)\end{array}$ & $\begin{array}{c}0.002 \\
(0.018)\end{array}$ & $\begin{array}{l}-0.025 \\
(0.023)\end{array}$ & $\begin{array}{l}-0.007 \\
(0.020)\end{array}$ & $\begin{array}{l}-0.994 \\
(0.652)\end{array}$ \\
\hline & Working's T Natural Gas & $\begin{array}{c}0.024 \\
(0.016)\end{array}$ & $\begin{array}{c}0.015 \\
(0.021)\end{array}$ & $\begin{array}{l}-0.002 \\
(0.013)\end{array}$ & $\begin{array}{c}0.014 \\
(0.016)\end{array}$ & $\begin{array}{l}-0.009 \\
(0.015)\end{array}$ & $\begin{array}{l}-0.567 \\
(0.474)\end{array}$ \\
\hline & Working's T Crude Oil & $\begin{array}{l}-0.039 \\
(0.031)\end{array}$ & $\begin{array}{l}-0.035 \\
(0.045)\end{array}$ & $\begin{array}{l}-0.018 \\
(0.026)\end{array}$ & $\begin{array}{l}-0.039 \\
(0.032)\end{array}$ & $\begin{array}{c}0.014 \\
(0.030)\end{array}$ & $\begin{array}{c}0.739 \\
(1.045)\end{array}$ \\
\hline & Constant & $\begin{array}{c}0.061 \\
(0.046)\end{array}$ & $\begin{array}{c}0.039 \\
(0.058)\end{array}$ & $\begin{array}{c}0.052 \\
(0.038)\end{array}$ & $\begin{array}{c}0.059 \\
(0.045)\end{array}$ & $\begin{array}{c}0.065 \\
(0.041)\end{array}$ & $\begin{array}{l}2.542 * \\
(1.412)\end{array}$ \\
\hline \multirow{12}{*}{ 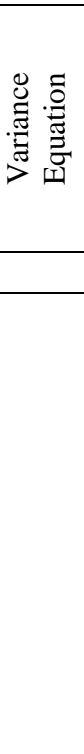 } & $\mathrm{ARCH}(1)$ & $\begin{array}{c}0.104 * * * \\
(0.020)\end{array}$ & $\begin{array}{c}0.075^{* * *} \\
(0.024)\end{array}$ & $\begin{array}{c}0.115^{* * * *} \\
(0.017)\end{array}$ & $\begin{array}{c}0.089 * * * \\
(0.024)\end{array}$ & $\begin{array}{c}0.050 * * * \\
(0.014)\end{array}$ & $\begin{array}{c}0.144 * * * \\
(0.032)\end{array}$ \\
\hline & $\operatorname{GARCH}(1)$ & $\begin{array}{c}0.840 * * * \\
(0.031)\end{array}$ & $\begin{array}{c}0.826^{* * * *} \\
(0.062)\end{array}$ & $\begin{array}{c}0.849 * * * \\
(0.020)\end{array}$ & $\begin{array}{c}0.861 * * * \\
(0.043)\end{array}$ & $\begin{array}{c}0.906 * * * \\
(0.027)\end{array}$ & $\begin{array}{c}0.805 * * * \\
(0.042)\end{array}$ \\
\hline & Constant & $\begin{array}{c}0.000 * * * \\
(0.000)\end{array}$ & $\begin{array}{c}0.000^{* *} \\
(0.000)\end{array}$ & $\begin{array}{c}0.000 * * * \\
(0.000)\end{array}$ & $\begin{array}{l}0.000 * * \\
(0.000)\end{array}$ & $\begin{array}{c}0.000 * * \\
(0.000)\end{array}$ & $\begin{array}{c}0.050 * * * \\
(0.019)\end{array}$ \\
\hline & F-stat on Working's T & 9.180 & 8.170 & 14.450 & 11.390 & $14.790 *$ & $17.760 * *$ \\
\hline & Log Likelihood & & & & 11330 & & \\
\hline & AIC & & & & -22347 & & \\
\hline & $\mathrm{BIC}$ & & & & -21570 & & \\
\hline & Degree of Freedom & & & & $\begin{array}{l}.671 * * * \\
(0.961)\end{array}$ & & \\
\hline & Lambda 1 & & & & $\begin{array}{l}.016 * * * \\
(0.004)\end{array}$ & & \\
\hline & Lambda 2 & & & & $\begin{array}{l}.952 * * * \\
(0.013)\end{array}$ & & \\
\hline & $\begin{array}{l}\text { Test for Lambda } 1=\text { Lambda } 2=0 \\
(\text { Chi2(2)) }\end{array}$ & & & & $481.110^{* * *}$ & & \\
\hline & N. of Obs. & 1076 & 1076 & 1076 & 1076 & 1076 & 1076 \\
\hline
\end{tabular}

Notes: The error distribution is a multivariate Student's T. Standard errors in parentheses. * significant at 10\% level, ** significant at 5\% level, $* * *$ significant at $1 \%$ level. 
Table 11.b: Descriptive statistics for dynamic conditional correlations on "agriculture + factor of energy variables" group

\begin{tabular}{lcccccrr}
\hline \hline Returns & N. of Obs. & Mean & Std. Dev. & Min & Max & Skew. & Kurt. \\
\hline Corn, Oats & 1076 & 0.488 & 0.073 & 0.016 & 0.605 & -2.218 & 10.706 \\
Corn, Soybeans & 1076 & 0.592 & 0.075 & 0.019 & 0.703 & -3.233 & 19.297 \\
Corn, Wheat & 1076 & 0.514 & 0.080 & 0.017 & 0.665 & -2.102 & 11.044 \\
Corn, Soybean Oil & 1076 & 0.464 & 0.068 & 0.015 & 0.592 & -1.909 & 10.613 \\
Corn, Energy factor & 1076 & 0.060 & 0.062 & -0.057 & 0.306 & 1.063 & 4.500 \\
Oats, Soybeans & 1076 & 0.345 & 0.060 & 0.011 & 0.539 & -0.676 & 5.206 \\
Oats, Wheat & 1076 & 0.357 & 0.067 & 0.012 & 0.496 & -0.990 & 5.836 \\
Oats, Soybean Oil & 1076 & 0.318 & 0.055 & 0.010 & 0.522 & -0.454 & 5.572 \\
Oats, Energy factor & 1076 & 0.072 & 0.060 & -0.111 & 0.248 & 0.188 & 3.007 \\
Soybeans, Wheat & 1076 & 0.329 & 0.070 & 0.011 & 0.477 & -0.916 & 4.410 \\
Soybeans, Soybean Oil & 1076 & 0.680 & 0.081 & 0.022 & 0.798 & -3.657 & 23.293 \\
Soybeans, Energy factor & 1076 & 0.119 & 0.068 & -0.026 & 0.380 & 0.977 & 4.372 \\
Wheat, Soybean Oil & 1076 & 0.284 & 0.064 & 0.010 & 0.447 & -0.555 & 4.163 \\
Wheat, Energy factor & 1076 & 0.091 & 0.052 & -0.056 & 0.239 & 0.298 & 2.506 \\
Soybean Oil, Energy factor & 1076 & 0.143 & 0.083 & -0.024 & 0.435 & 1.138 & 4.114 \\
\hline \hline
\end{tabular}

Table 12.a: Mean tests on dynamic conditional correlations of "fuels" group

\begin{tabular}{lccccr}
\hline \multirow{2}{*}{ Returns } & \multicolumn{3}{c}{ Obs. } & \multicolumn{2}{c}{ Mean } \\
\cline { 2 - 5 } & Before 2004 & After 2004 & Before 2004 & After 2004 & \\
\hline Gasoline, Heating Oil & 713 & 363 & 0.692 & 0.733 & $-10.340^{* * *}$ \\
Gasoline, Natural Gas & 713 & 363 & 0.203 & 0.250 & $-8.946^{* * *}$ \\
Gasoline, Crude Oil & 713 & 363 & 0.717 & 0.733 & $-4.290^{* * *}$ \\
Gasoline, Soybean Oil & 713 & 363 & 0.104 & 0.182 & $-15.046^{* * *}$ \\
Heating Oil, Natural Gas & 713 & 363 & 0.320 & 0.350 & $-6.355^{* * *}$ \\
Heating Oil, Crude Oil & 713 & 363 & 0.767 & 0.786 & $-5.262^{* * *}$ \\
Heating Oil, Soybean Oil & 713 & 363 & 0.134 & 0.223 & $-15.924^{* * *}$ \\
Natural Gas, Crude Oil & 713 & 363 & 0.211 & 0.236 & $-4.678^{* * *}$ \\
Natural Gas, Soybean Oil & 713 & 363 & 0.115 & 0.157 & $-8.784^{* * *}$ \\
Crude Oil, Soybean Oil & 713 & 363 & 0.097 & 0.183 & $-15.981^{* * *}$ \\
\hline \hline
\end{tabular}

Notes: * significant at $10 \%$ level, ** significant at $5 \%$ level, *** significant at $1 \%$ level. 
Table 12.b: Mean tests on dynamic conditional correlations of "agriculture" group

\begin{tabular}{lccccc}
\hline \hline \multirow{2}{*}{ Returns } & \multicolumn{3}{c}{ Obs. } & \multicolumn{2}{c}{ Mean } \\
\cline { 2 - 5 } & Before 2004 & After 2004 & Before 2004 & After 2004 \\
\hline Corn, Oats & 933 & 364 & 0.476 & 0.493 & $-3.646^{* * * *}$ \\
Corn, Soybeans & 933 & 364 & 0.609 & 0.604 & 0.982 \\
Corn, Wheat & 933 & 364 & 0.504 & 0.526 & $-4.660^{* * *}$ \\
Corn, Soybean Oil & 933 & 364 & 0.481 & 0.495 & $-3.381^{* * *}$ \\
Oats, Soybeans & 933 & 364 & 0.377 & 0.378 & -0.122 \\
Oats, Wheat & 933 & 364 & 0.347 & 0.377 & $-7.029 * * *$ \\
Oats, Soybean Oil & 933 & 364 & 0.334 & 0.362 & $-7.037 * * *$ \\
Soybeans, Wheat & 933 & 364 & 0.340 & 0.343 & -0.539 \\
Soybeans, Soybean Oil & 933 & 364 & 0.678 & 0.711 & $-7.761^{* * *}$ \\
Wheat, Soybean Oil & 933 & 364 & 0.277 & 0.302 & $-5.863 * * *$ \\
\hline \hline
\end{tabular}

Notes: * significant at $10 \%$ level, $* *$ significant at $5 \%$ level, $* * *$ significant at $1 \%$ level.

Table 12.c: Mean tests on dynamic conditional correlations of "agriculture + factor of energy variables" group

\begin{tabular}{lccccc}
\hline \hline \multirow{2}{*}{ Returns } & \multicolumn{2}{c}{ Obs. } & \multicolumn{2}{c}{ Mean } & t-stat \\
\cline { 2 - 5 } & Before 2004 & After 2004 & Before 2004 & After 2004 \\
\hline Corn, Oats & 713 & 363 & 0.482 & 0.499 & $-3.748^{* * *}$ \\
Corn, Soybeans & 713 & 363 & 0.591 & 0.594 & -0.568 \\
Corn, Wheat & 713 & 363 & 0.506 & 0.530 & $-4.739 * * *$ \\
Corn, Soybean Oil & 713 & 363 & 0.455 & 0.480 & $-5.716^{* * *}$ \\
Corn, Energy factor & 713 & 363 & 0.043 & 0.092 & $-13.260^{* * *}$ \\
Oats, Soybeans & 713 & 363 & 0.341 & 0.352 & $-3.099^{* * *}$ \\
Oats, Wheat & 713 & 363 & 0.344 & 0.382 & $-9.207^{* * *}$ \\
Oats, Soybean Oil & 713 & 363 & 0.305 & 0.343 & $-11.055^{* * *}$ \\
Oats, Energy factor & 713 & 363 & 0.059 & 0.096 & $-9.869^{* * *}$ \\
Soybeans, Wheat & 713 & 363 & 0.326 & 0.335 & $-1.868^{*}$ \\
Soybeans, Soybean Oil & 713 & 363 & 0.667 & 0.708 & $-8.377^{* * *}$ \\
Soybeans, Energy factor & 713 & 363 & 0.093 & 0.170 & $-20.795^{* * *}$ \\
Wheat, Soybean Oil & 713 & 363 & 0.274 & 0.304 & $-7.442^{* * * *}$ \\
Wheat, Energy factor & 713 & 363 & 0.082 & 0.110 & $-8.477^{* * *}$ \\
Soybean Oil, Energy factor & 713 & 363 & 0.104 & 0.218 & $-27.458^{* * * *}$ \\
\hline \hline
\end{tabular}

Notes: * significant at $10 \%$ level, $* *$ significant at $5 \%$ level, $* * *$ significant at $1 \%$ level. 
Figure 1: Plot of 1-month futures prices across commodities (in US \$)
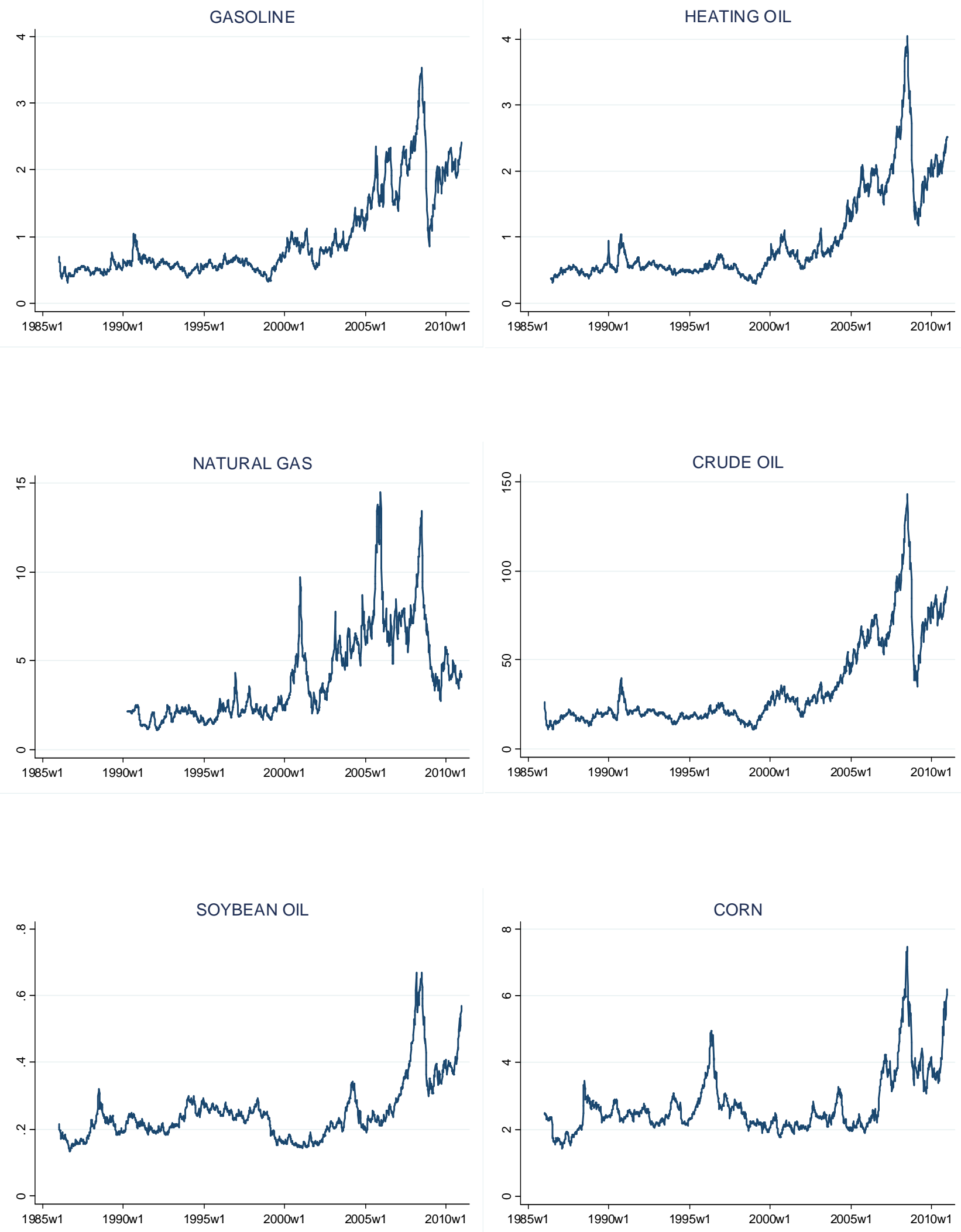

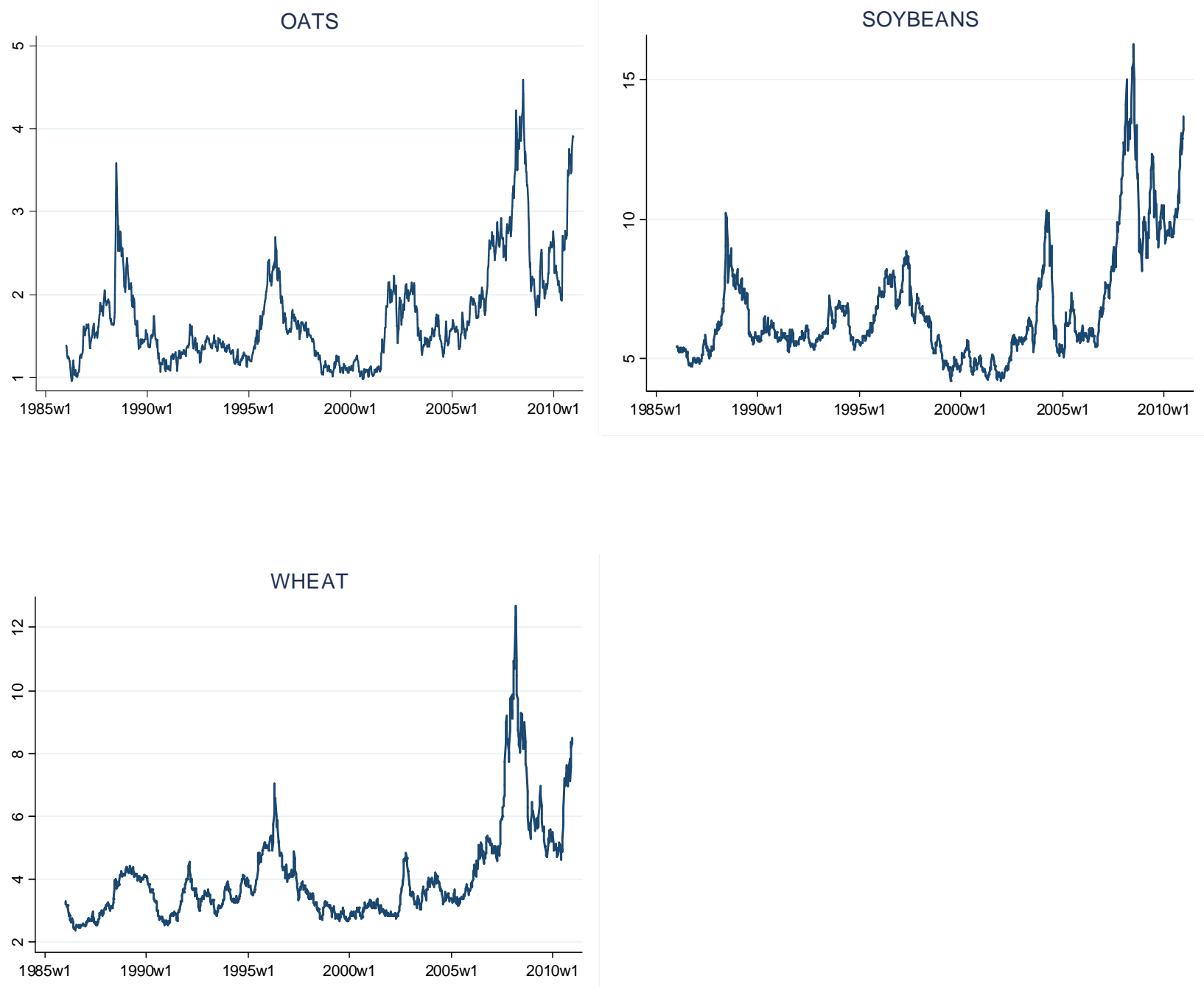
Figure 2.a: Conditional correlations of DCC model on “fuels" group
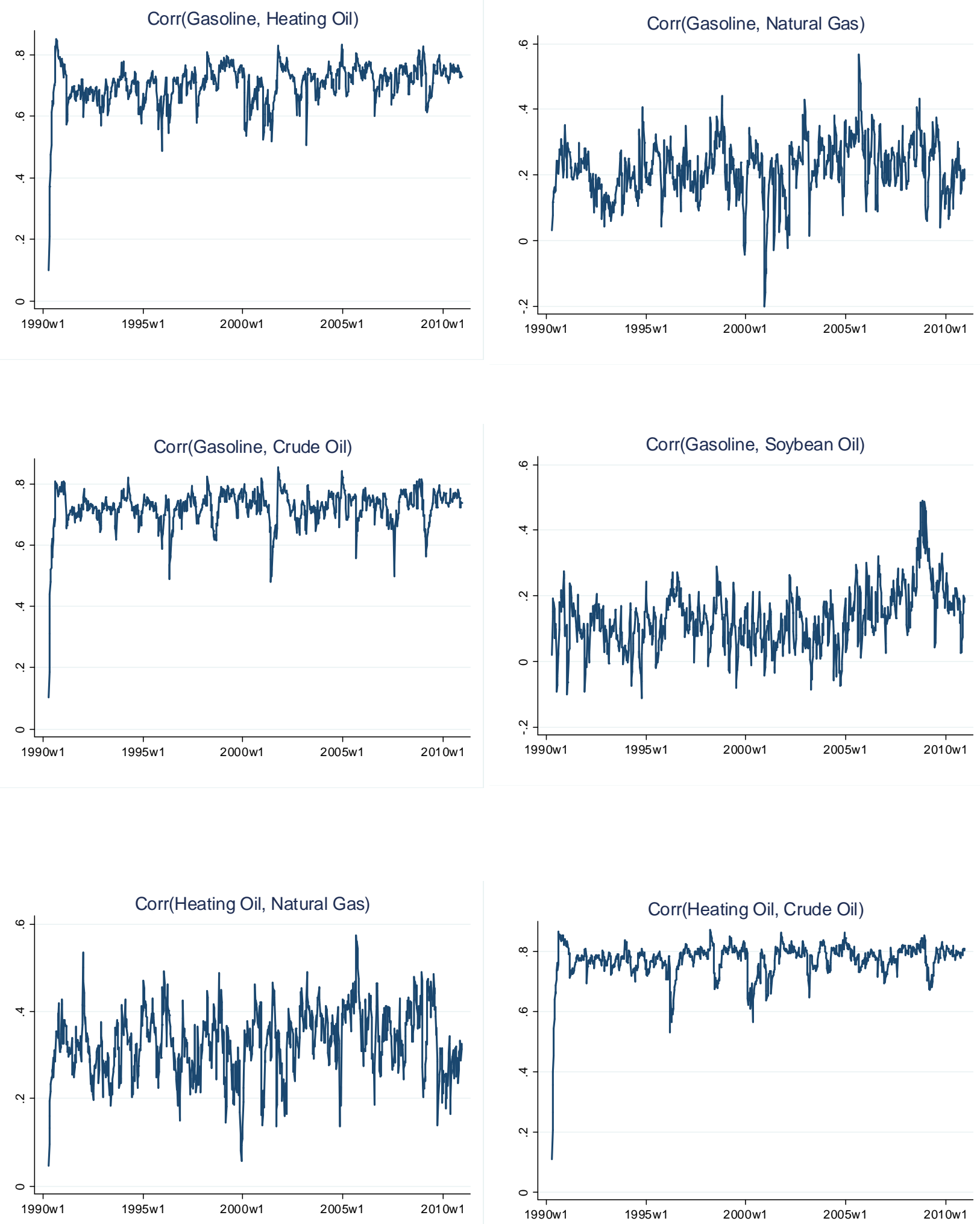

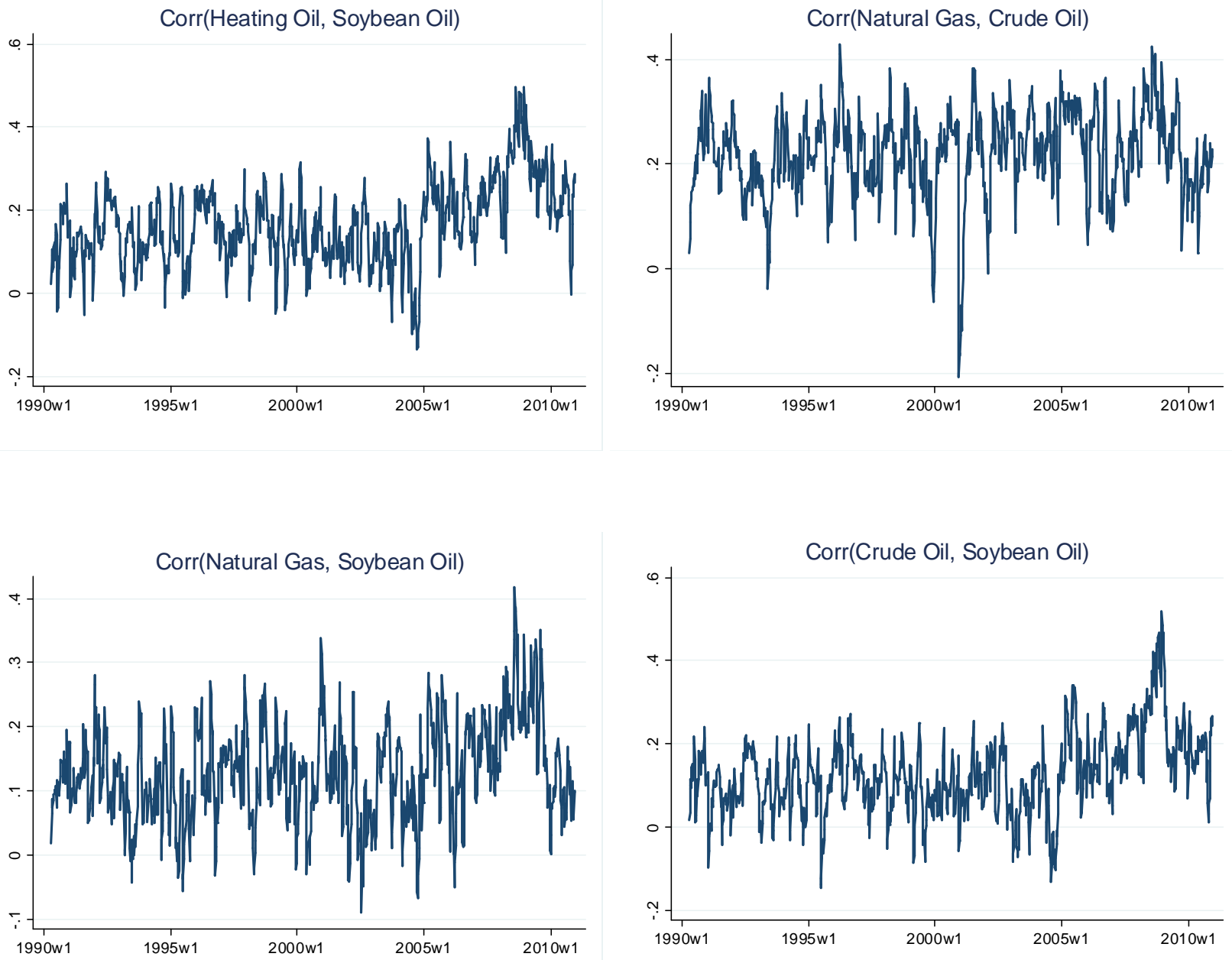
Figure 2.b: Conditional correlations of DCC model on "agriculture" group
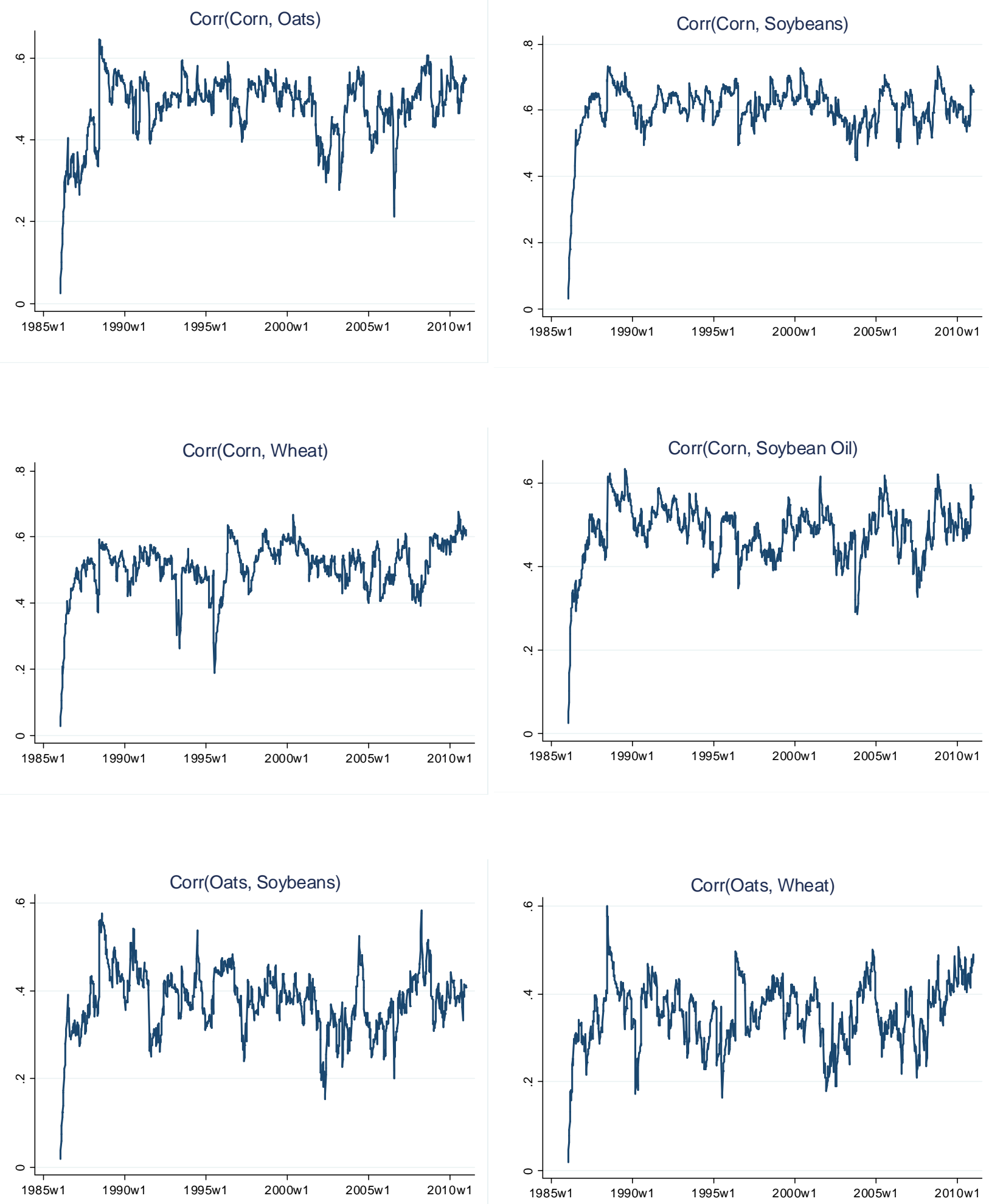

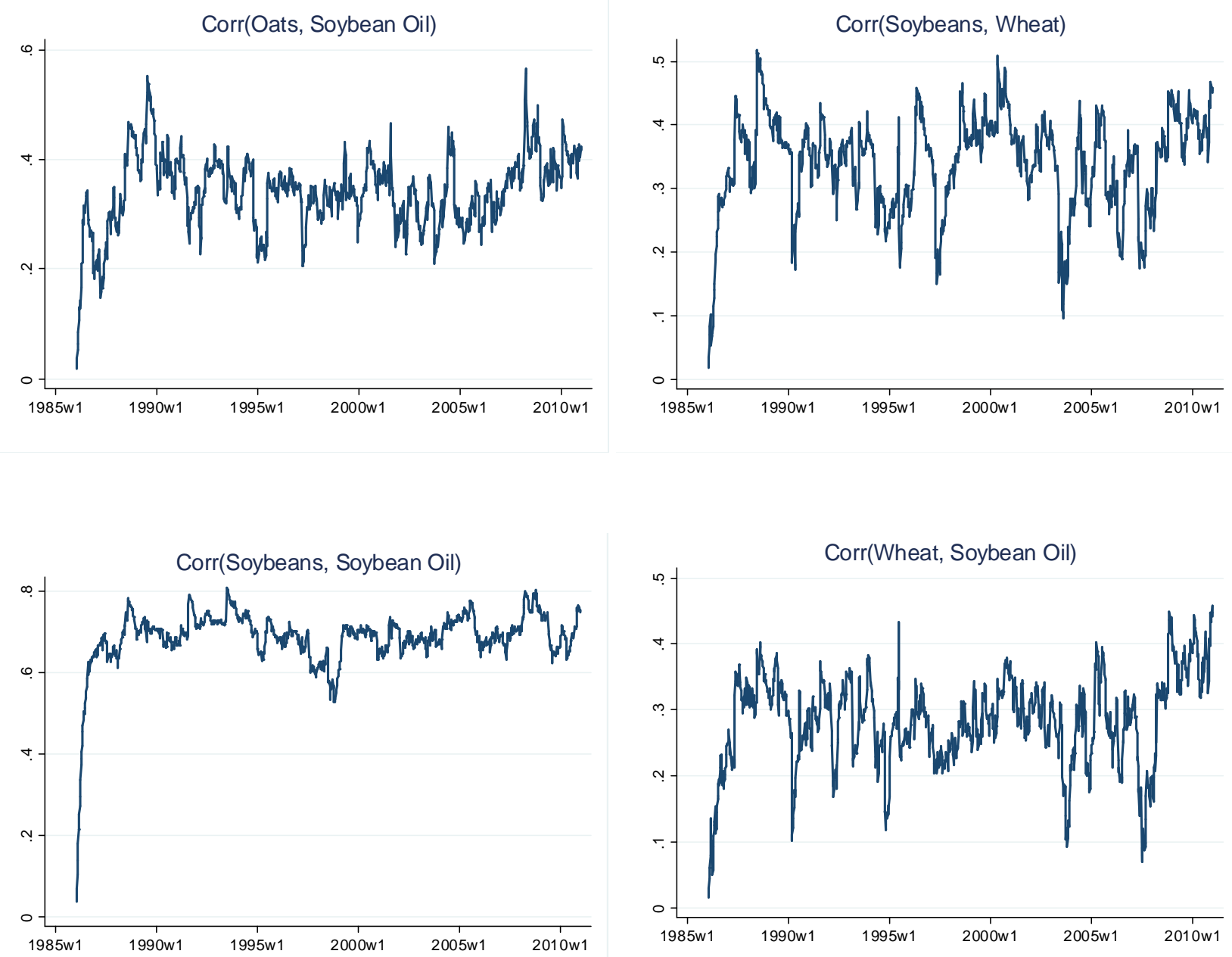
Figure 2.c: Conditional correlations of DCC model on "agriculture + factor of energy variables" group
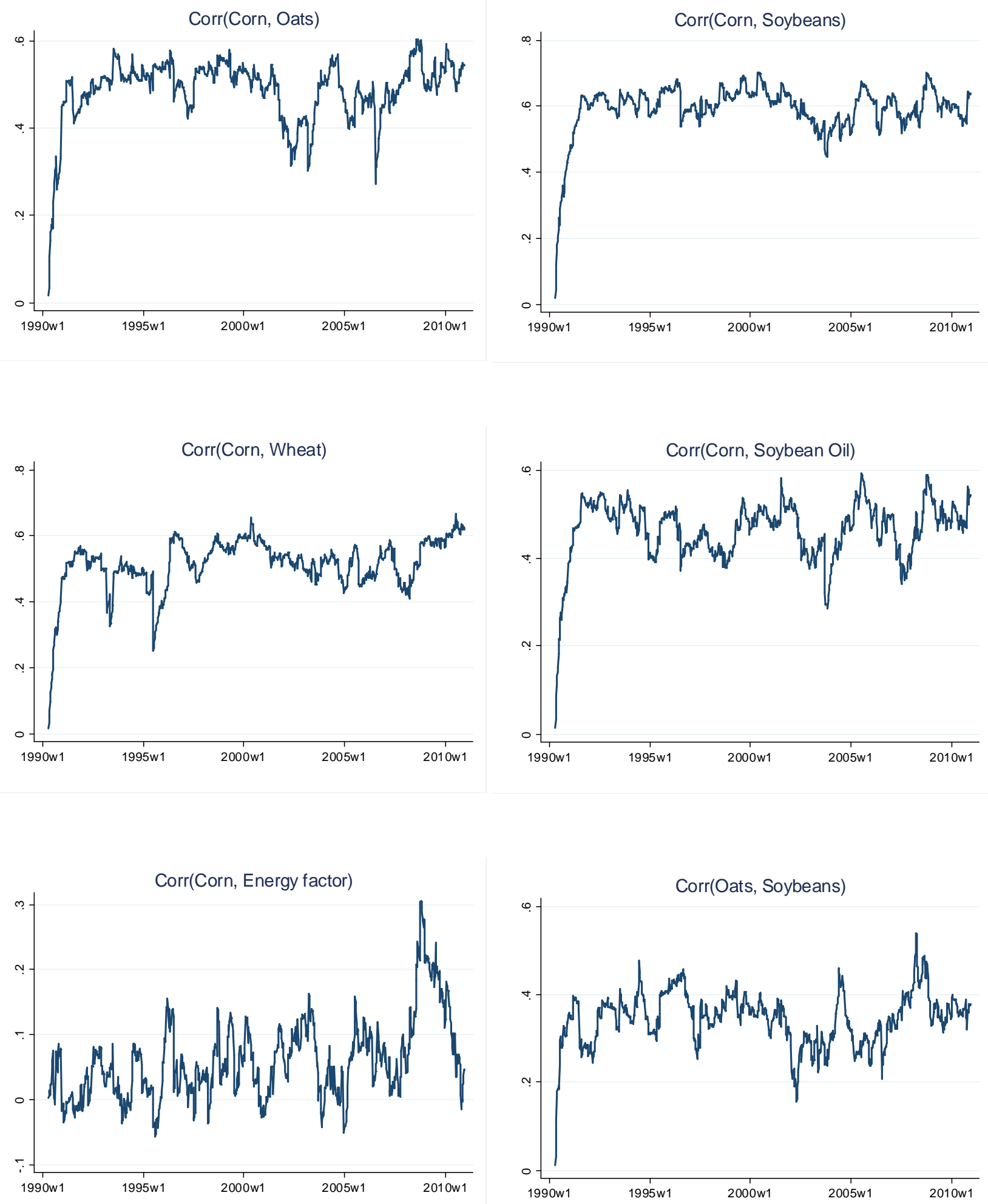

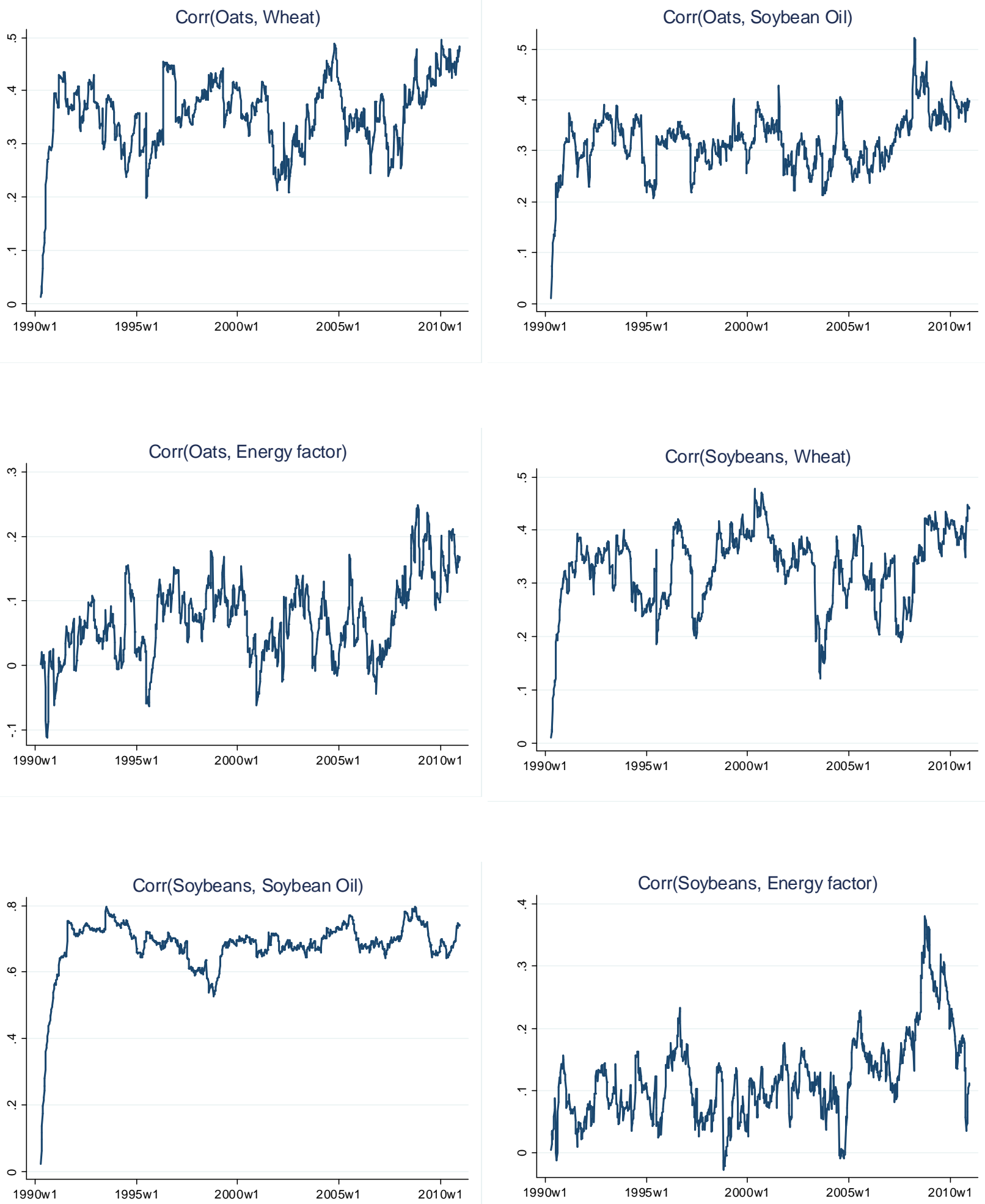

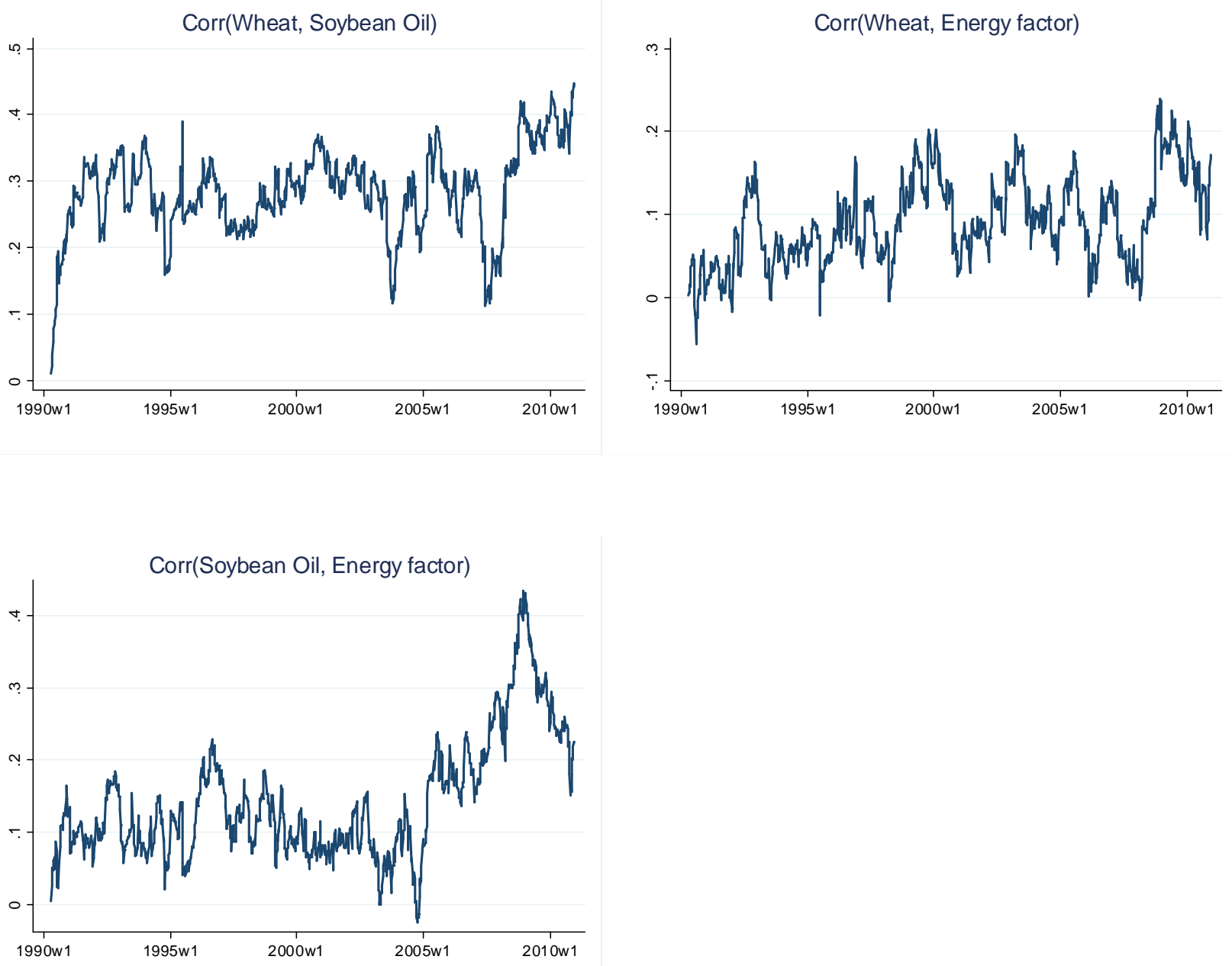